\title{
How emissions, climate, and land use change will impact mid-century air quality over the United States: a focus on effects at national parks
}

\author{
M. Val Martin ${ }^{1,2}$, C. L. Heald ${ }^{3}$, J.-F. Lamarque ${ }^{4}$, S. Tilmes ${ }^{4}$, L. K. Emmons ${ }^{4}$, and B. A. Schichtel ${ }^{5,6}$ \\ ${ }^{1}$ Atmospheric Science Department, Colorado State University, Fort Collins, CO, USA \\ ${ }^{2}$ Chemical and Biological Engineering Department, The University of Sheffield, Sheffield, UK \\ ${ }^{3}$ Department of Civil and Environmental Engineering, Massachusetts Institute of Technology, \\ Cambridge, MA, USA \\ ${ }^{4}$ National Center for Atmospheric Research, Boulder, CO, USA \\ ${ }^{5}$ National Park Service, Fort Collins, CO, USA \\ ${ }^{6}$ Cooperative Institute for Research in the Atmosphere, Fort Collins, CO, USA
}

Correspondence to: M. Val Martin (m.valmartin@sheffield.ac.uk)

Received: 3 October 2014 - Published in Atmos. Chem. Phys. Discuss.: 22 October 2014

Revised: 12 February 2015 - Accepted: 18 February 2015 - Published: 10 March 2015

\begin{abstract}
We use a global coupled chemistry-climate-land model (CESM) to assess the integrated effect of climate, emissions and land use changes on annual surface $\mathrm{O}_{3}$ and $\mathrm{PM}_{2.5}$ in the United States with a focus on national parks (NPs) and wilderness areas, using the RCP4.5 and RCP8.5 projections. We show that, when stringent domestic emission controls are applied, air quality is predicted to improve across the US, except surface $\mathrm{O}_{3}$ over the western and central US under RCP8.5 conditions, where rising background ozone counteracts domestic emission reductions. Under the RCP4.5 scenario, surface $\mathrm{O}_{3}$ is substantially reduced (about $5 \mathrm{ppb}$ ), with daily maximum $8 \mathrm{~h}$ averages below the primary US Environmental Protection Agency (EPA) National Ambient Air Quality Standards (NAAQS) of $75 \mathrm{ppb}$ (and even $65 \mathrm{ppb}$ ) in all the NPs. $\mathrm{PM}_{2.5}$ is significantly reduced in both scenarios $\left(4 \mu \mathrm{g} \mathrm{m}^{-3} ; \sim 50 \%\right)$, with levels below the annual US EPA NAAQS of $12 \mu \mathrm{g} \mathrm{m}^{-3}$ across all the NPs; visibility is also improved (10-15 dv; $>75 \mathrm{~km}$ in visibility range), although some western US parks with Class I status (40-74\% of total sites in the US) are still above the 2050 planned target level to reach the goal of natural visibility conditions by 2064. We estimate that climate-driven increases in fire activity may dominate summertime $\mathrm{PM}_{2.5}$ over the western US, potentially offsetting the large $\mathrm{PM}_{2.5}$ reductions from domes-
\end{abstract}

tic emission controls, and keeping visibility at present-day levels in many parks. Our study indicates that anthropogenic emission patterns will be important for air quality in 2050 . However, climate and land use changes alone may lead to a substantial increase in surface $\mathrm{O}_{3}(2-3 \mathrm{ppb})$ with important consequences for $\mathrm{O}_{3}$ air quality and ecosystem degradation at the US NPs. Our study illustrates the need to consider the effects of changes in climate, vegetation, and fires in future air quality management and planning and emission policy making.

\section{Introduction}

Air pollution, such as surface ozone $\left(\mathrm{O}_{3}\right)$ and fine particulate matter (with diameter $<2.5 \mu \mathrm{m} ; \mathrm{PM}_{2.5}$ ), has evolved in both urban and rural regions around the world over the last centuries. Air pollution changes have resulted in part from direct changes in natural and anthropogenic emissions and in part from indirect changes associated with climate and land use (Jacob and Winner, 2009; Arneth et al., 2010; Fiore et al., 2012). A changing climate is projected to significantly modify both natural and anthropogenic emissions and the atmospheric processes that govern air pollution trans- 
port, transformation, and deposition. For example, a warming climate is expected to increase wildfires and associated emissions of trace gases and particulate matter (Spracklen et al., 2009; Yue et al., 2013), cause a general increase in biogenic emissions (Heald et al., 2008), and increase emissions of $\mathrm{O}_{3}$ and aerosol precursors, such as nitrogen oxides $\left(\mathrm{NO}_{\mathrm{x}}\right)$ and ammonia $\left(\mathrm{NH}_{3}\right)$, from soil and agricultural activities. Anthropogenic emissions are likely to change in response to economic, climatic, and political pressures and policies (IPCC, 2013). In addition, a changing climate is likely to alter precipitation and cloud patterns and synoptic-scale transport processes (Jacob and Winner, 2009). At the same time, changes in land cover and land use will influence the deposition of pollution, as well as the emission of $\mathrm{O}_{3}$ and aerosol precursors (Ganzeveld et al., 2010; Wu et al., 2012). For example, deforestation decreases turbulent exchange and foliar uptake, prompting a rise in air pollutants. These effects may drive significant local increases or decreases in air pollution.

National parks (NPs) and wilderness areas in the United States (US) are visited by millions of people every year to enjoy pristine nature. Maintaining adequate air quality conditions in these areas is key to preserving natural ecosystems, preventing negative impacts on visitor and staff health, and maximizing the beauty of landscapes. Air quality management in these regions, including efforts to develop meaningful emissions control strategies, relies on assessment of the current as well as future contributions of natural and anthropogenic sources to local air quality.

Two recent literature reviews (Jacob and Winner, 2009; Fiore et al., 2012) indicate that climate change alone will increase summertime surface ozone in polluted areas by $1-$ $10 \mathrm{ppb}$. Pfister et al. (2014) predict an increase of about $5 \mathrm{ppb}$ over the Rocky Mountain region during the summer in a future climate, with important implications for the US National Park Service air quality management. Surface $\mathrm{O}_{3}$ is toxic to humans and thus poses a threat to visitor and park staff health. In addition, accumulated exposure to elevated levels of $\mathrm{O}_{3}$ can damage vegetation (e.g., Reich and Amundson, 1985; Schaub et al., 2005). Ozone levels have been shown to cause significant yield reduction in a number of major crops on a global scale (e.g., Avnery et al., 2011; Ghude et al., 2014) and, in combination with warming, may reduce global crop production by up to $15 \%$ in 2050 (Tai et al., 2014), leading to substantial economic losses and potentially worsening global malnutrition. Studies have also reported many other negative impacts on ecosystems, such as reductions in tree and seedling growth, decreases in photosynthetic rates, and visible foliar injuries on multiple plant species, including broadleaf deciduous forest in the northeastern US and needleleaf evergreen forest in the western US (e.g., Arbaugh et al., 1998; Schaub et al., 2005). In addition, rising $\mathrm{O}_{3}$ levels may substantially suppress the global land-carbon sink via its negative effect on photosynthesis, leading to a greater accumulation of carbon dioxide in the atmosphere (Sitch et al., 2007).
Atmospheric fine particles are also harmful to human and ecosystem health. Short-term exposure to $\mathrm{PM}_{2.5}$ can lead to respiratory illness such as asthma; longer-term exposure may result in more severe cardiovascular and respiratory diseases as well as lung cancer, increasing the risk of premature mortality (e.g., Pope and Dockery, 2006). Fine particles and gases cause haze, which degrades visibility. Visibility is a protected attribute of some remote locations known as Class I areas, which includes many NPs and wilderness areas. The 1977 Clean Air Act set forth the goal to prevent future and remedy existing visibility impairment in Class I areas. In response, the US Environmental Protection Agency (EPA) promulgated the Regional Haze Rule (RHR), which established the goal of returning visibility to natural conditions by the year 2064. Specifically, the RHR mandates that each state set "reasonable progress" goals to return visibility to natural conditions on the $20 \%$ haziest days by 2064 , while preventing further degradation of visibility on the $20 \%$ clearest days (US EPA, 2003). Wild and prescribed fires are one of the primary contributors to air pollution, including haze-causing pollutants, in the western and southeastern US (e.g., Val Martin et al., 2013). Previous studies project that increased fire activity over the western United States will nearly double carbonaceous aerosol by 2050 , and produce a significant increase in annual mean $\mathrm{PM}_{2.5}$ and haze (Spracklen et al., 2009; Yue et al., 2013).

In this study, we examine the integrated effect of climate change, anthropogenic emission changes, and land use change on air quality over the United States, with a particular focus on the US national parks. To our knowledge, this is the first time that the relative effect of these three factors has been considered for US air quality projection. We use a global earth system model to estimate how surface $\mathrm{O}_{3}$ and $\mathrm{PM}_{2.5}$ are expected to change using two Representative Concentration Pathway (RCP) scenarios, represented in the IPCC (2013). We assess the changes in surface $\mathrm{O}_{3}$ and $\mathrm{PM}_{2.5}$ in 2050 relative to present-day levels and discuss the meteorological and chemical drivers behind these changes.

\section{Modeling analysis}

\subsection{Model description and future changes}

To simulate the impact of future changes on the US air quality, we use the Community Earth System Model (CESM; http://www2.cesm.ucar.edu/). CESM is a global model, which includes atmospheric, land, ocean and sea ice models that can be run in stand-alone or coupled configurations. We run CESM version 1.1.1 with online computed meteorology and prescribed sea-surface and sea-ice distributions, corresponding to previous fully coupled simulations. Simulations are performed at the horizontal resolution of $1.9^{\circ} \times 2.5^{\circ}$, and vertical resolution of 26 layers from the surface to about $4 \mathrm{hPa}$, with a time step of $30 \mathrm{~min}$. 
To simulate land processes, we use the Community Land Model (CLM) version 4 (Oleson et al., 2010). CLM describes the physical, chemical, and biological processes of terrestrial ecosystems, including the hydrology and carbon cycling of the terrestrial biosphere.

For the atmospheric model, we use the Community Atmospheric Model (CAM) version 4 (Neale et al., 2013) fully coupled with an interactive gas-aerosol scheme (CAMChem) (Lamarque et al., 2012; Tilmes et al., 2014). The chemical mechanism includes full tropospheric $\mathrm{O}_{3}-$ $\mathrm{NO}_{\mathrm{x}}-\mathrm{CO}-\mathrm{VOC}$ and aerosol phase chemistry, based on the MOZART-4 chemical transport model (Emmons et al., 2010). Simulated aerosol mass classes include sulfate $\left(\mathrm{SO}_{4}\right)$, ammonium nitrate $\left(\mathrm{NH}_{4} \mathrm{NO}_{3}\right)$, primary carbonaceous aerosols (black carbon, organic carbon), secondary organic aerosols (SOA), sea salt and dust. $\mathrm{SO}_{4}$ is formed from the oxidation of $\mathrm{SO}_{2}$ in the gas phase (by reaction with the hydroxyl radical) and in the aqueous phase (by reaction with ozone and hydrogen peroxide). $\mathrm{NH}_{4} \mathrm{NO}_{3}$ is determined from $\mathrm{NH}_{3}$ emissions and the parameterization of gas/aerosol partitioning by Metzger et al. (2002), which is based on the level of sulfate present. Black carbon (BC) and organic carbon (OC) aerosols are directly emitted in a combination of hydrophobic and hydrophilic forms (80 and $50 \%$ hydrophobic, respectively), and hydrophobic aerosol is converted to hydrophilic with a fixed 1.6 days $E$-folding time (Tie et al., 2005). Dust and sea salt are implemented following Mahowald et al. (2006a, b), with improvements from Albani et al. (2014); the sources of these natural aerosols are derived based on the model calculated wind speed and surface conditions. SOA formation is linked to the gas-phase chemistry through the oxidation of isoprene, monoterpenes, alkenes and toluene as in Lack et al. (2004). Finally, dry deposition is represented by the multiple resistance approach of Wesely (1989), with some updates (Emmons et al., 2010; Lamarque et al., 2012; Val Martin et al., 2014). The calculation of dry deposition velocities is performed in CLM and linked to land cover types. Therefore, dry deposition responds to changes in land cover and climate. In this work, we use the optimized dry deposition scheme described in Val Martin et al. (2014), in which the vegetation resistances are linked to the leaf area index (LAI). This optimized dry deposition scheme improves the simulation of $\mathrm{O}_{3}$ dry deposition velocity, particularly over broadleaf forested regions, and significantly reduces the well-known, long lasting summertime surface $\mathrm{O}_{3}$ bias over eastern US and Europe in CAM-Chem documented by Lamarque et al. (2012); we discuss this further in Sect. 2.2.

We perform time-slice experiments for 2000 (present-day and baseline) and 2050 (future), under the RCP scenarios designed in support of the IPCC AR5. The RCP includes four scenarios, each of which corresponds to a specific pathway towards reaching a 2100 target radiative forcing (RF) (i.e., 2.6, 4.5, 6.0 and $8.5 \mathrm{Wm}^{-2}$ ) associated with greenhouse gases: RCP2.6, RCP4.5, RCP6.0 and RCP8.5, respectively. The RCP2. 6 assumes a peak forcing $\left(3.0 \mathrm{Wm}^{-2}\right)$ in the early
Table 1. Summary of main RCP4.5 and RCP8.5 anthropogenic greenhouse gas concentrations and global area-averaged sea-surface temperature (SST) for 2000 and 2050.

\begin{tabular}{cccccc}
\hline Year & Scenario & $\begin{array}{c}\mathrm{CO}_{2} \\
(\mathrm{ppm})\end{array}$ & $\begin{array}{c}\mathrm{CH}_{4} \\
(\mathrm{ppb})\end{array}$ & $\begin{array}{c}\mathrm{N}_{2} \mathrm{O} \\
(\mathrm{ppb})\end{array}$ & $\begin{array}{c}\mathrm{SST} \\
\left({ }^{\circ} \mathrm{C}\right)\end{array}$ \\
\hline 2000 & Baseline & 367 & 1760 & 316 & 12.2 \\
2050 & RCP4.5 & 487 & 1833 & 350 & 12.6 \\
& RCP8.5 & 541 & 2740 & 367 & 13.0 \\
\hline
\end{tabular}

21 st century and a decline out to 2100 , the RCP4.5 and RCP6.0 scenarios assume RF stabilization after 2100, and the RCP8.5 scenario assumes continuing growth in RF after 2100 (Moss et al., 2011). In this work, we select the RCP4.5 and RCP8.5 scenarios to bracket our results, i.e., we use a stabilization scenario (RCP4.5) and the largest forcing scenario (RCP8.5). Table 1 summarizes the main climate input data for 2000 and 2050. We apply monthly mean time varying sea-surface temperatures and sea-ice distributions generated by the Community Climate System Model version 4 for the Coupled Model Intercomparison Project Phase 5 (Meehl et al., 2012). Our simulations also consider time varying, zonally averaged greenhouse gas distributions for $\mathrm{CO}_{2}, \mathrm{CH}_{4}$, $\mathrm{N}_{2} \mathrm{O}$ and halogens, and future changes in stratospheric ozone levels.

Table 2 summarizes the main anthropogenic emissions for short-lived air pollutants and biogenic emissions projected over the United States. We divide the emissions for eastern and western US because of the different emission patterns. Emissions of $\mathrm{NO}_{\mathrm{x}}, \mathrm{NH}_{3}, \mathrm{CO}$, non-methane non-methane volatile organic compounds (VOCs) $\mathrm{SO}_{2}$ and carbonaceous aerosols for anthropogenic activities and biomass burning are provided for 2000 by Lamarque et al. (2010) and for 2050 by the RCP database (van Vuuren et al., 2011, and references therein). Biomass burning emissions vary among the RCPs and in time, following changes in land cover and land use; however, they do not respond to changes in climate. Biogenic VOCs (e.g., isoprene and monoterpenes) are computed within CLM using the Model of Emissions of Gases and Aerosols from Nature (MEGAN v2.1) algorithms (Guenther et al., 2012), and are allowed to respond interactively to temperature, light, soil moisture, leaf age, $\mathrm{CO}_{2}$ concentrations and vegetation density (Heald et al., 2008). In this work, we do not include the effect of $\mathrm{CO}_{2}$, which suppresses isoprene production at elevated levels (e.g., Heald et al., 2008); we acknowledge that this is a limitation which will lead to a slight overestimate in isoprene emissions in 2050 because the $\mathrm{CO}_{2}$ inhibition would suppress about $10 \%$ the isoprene emission efficiency. Both dust and sea salt are also emitted interactively in CESM (Mahowald et al., 2006a, b; Albani et al., 2014). Lightning $\mathrm{NO}_{\mathrm{x}}$ emissions are also calculated interactively in the model, as described in Lamarque et al. (2012). These emissions respond to climate and cannot be modified 
Table 2. Anthropogenic short-lived air pollutants and biogenic emissions in 2000 and 2050, projected by the RCP4.5 and RCP8.5 scenarios over the United States.

\begin{tabular}{|c|c|c|c|c|c|c|c|c|c|c|}
\hline \multirow[b]{2}{*}{ Year } & \multirow[b]{2}{*}{ Scenario } & \multicolumn{7}{|c|}{ Anthropogenic emissions $\mathrm{s}^{\mathrm{a}}$} & \multicolumn{2}{|c|}{ Biogenic emissions ${ }^{b}$} \\
\hline & & $\mathrm{BC}$ & $\mathrm{OC}$ & $\mathrm{CO}$ & $\mathrm{NO}_{\mathrm{x}}$ & $\mathrm{NH}_{3}$ & NMVOCs & $\mathrm{SO}_{2}$ & Isoprene & Monoterpenes \\
\hline \multicolumn{11}{|c|}{ eastern US } \\
\hline 2000 & Baseline & 0.29 & 0.41 & 70.38 & 4.82 & 1.53 & 1.96 & 6.30 & 20.5 & 6.3 \\
\hline 2050 & $\mathrm{RCP} 4.5$ & 0.15 & 0.19 & 8.70 & 1.04 & 1.92 & 0.90 & 0.80 & 33.7 & 9.4 \\
\hline 2050 & RCP8.5 & 0.03 & 0.06 & 7.99 & 1.35 & 2.21 & 0.36 & 0.63 & 27.8 & 8.0 \\
\hline \multicolumn{11}{|c|}{ western US } \\
\hline 2000 & Baseline & 0.10 & 0.15 & 25.82 & 1.58 & 1.36 & 0.64 & 1.77 & 7.4 & 2.5 \\
\hline 2050 & $\mathrm{RCP} 4.5$ & 0.05 & 0.08 & 3.55 & 0.39 & 1.81 & 0.30 & 0.29 & 9.4 & 3.0 \\
\hline 2050 & RCP8.5 & 0.02 & 0.03 & 7.20 & 0.79 & 2.16 & 0.15 & 0.54 & 9.6 & 3.3 \\
\hline
\end{tabular}

a Reported $\mathrm{TgC}_{\mathrm{yr}}{ }^{-1}$ for BC, OC and NMVOCs; $\mathrm{Tg} \mathrm{N} \mathrm{yr}^{-1}$ for $\mathrm{NO}_{\mathrm{x}}$ and $\mathrm{NH}_{3} ; \mathrm{Tg} \mathrm{Syr}^{-1}$ for $\mathrm{SO}_{2}$; and $\mathrm{Tg} \mathrm{CO} \mathrm{yr}^{-1}$ for CO.

${ }^{\mathrm{b}}$ Reported $\mathrm{TgC} \mathrm{yr}^{-1}$.

in the time-slice experiments. However, they are expected to have a very small impact on the overall surface ozone concentrations (Kaynak et al., 2008). The global annual lightning emissions change from $4.2 \mathrm{Tg} \mathrm{N} \mathrm{yr}^{-1}$ in 2000 to 4.4 and $4.8 \mathrm{Tg} \mathrm{N} \mathrm{yr}^{-1}$ in 2050 for the RCP4.5 and RCP8.5 scenarios, respectively. Other natural emissions of $\mathrm{O}_{3}$ and aerosols precursors (e.g., volcanoes, ocean and soil) may have some impact on surface $\mathrm{O}_{3}$ and $\mathrm{PM}_{2.5}$ on a regional scale over the United States. However, given the large uncertainties on how these emissions might vary in the future, we keep them constant at year 2000 levels.

In addition to climate forcing and emission changes, we include changes in land use induced by human activities in our simulations (Hurtt et al., 2011). We show projected 20502000 changes in crops, grasslands and trees over the US for the RCP4.5 and RCP8.5 scenarios in Fig. 1 as an example. The RCP4.5 scenario predicts an expansion of forested area, in particular over the eastern US $(10 \%)$ as a result of mitigation strategies for carbon emission reductions and a decline in agricultural land (8\%) due to this afforestation. Conversely, the RCP8.5 scenario predicts an important increase in agricultural land (up to $5 \%$ in eastern US) resulting from increasing population as well as grasslands $(\sim 10 \%)$ and a decline in forest cover $(2 \%)$.

For this study, we perform nine simulations: one simulation for present-day and four for each future scenario (Table 3). For the four simulations in the future, we modify one forcing at a time, and name these simulations after their future conditions, i.e., climate alone ("2050 Climate"), anthropogenic emissions including biomass burning emissions and methane levels ("2050 Emissions"), land cover and land use changes including climate-driven biogenic emissions ("2050 Land Use") and the combined effects of all the individual forcings ("2050 Total Change"). In the 2050 Land Use simulation, climate-driven biogenic emissions are precalculated using the 2050 RCP4.5 and RCP8.5 climate projections. Each model simulation is initialized with a 1-year spin-up run. Following initialization, present-day and future "snap-
Table 3. List of simulations ${ }^{\mathrm{a}}$.

\begin{tabular}{lccccc}
\hline Forcings & $\begin{array}{c}2000 \\
\text { Baseline }\end{array}$ & $\begin{array}{c}2050 \\
\text { Total }\end{array}$ & $\begin{array}{c}2050 \\
\text { Climate }\end{array}$ & $\begin{array}{c}2050 \\
\text { Emissions }\end{array}$ & $\begin{array}{c}2050 \\
\text { Land Use }\end{array}$ \\
\hline Climate & 2000 & 2050 & 2050 & 2000 & 2000 \\
Emissions ${ }^{\mathrm{b}}$ : & & & & & \\
Anthropogenic & 2000 & 2050 & 2000 & 2050 & 2000 \\
BB & 2000 & 2050 & 2000 & 2050 & 2000 \\
Biogenic & 2000 & 2050 & 2000 & 2000 & 2050 \\
Land Use $^{\mathrm{c}}$ & 2000 & 2050 & 2000 & 2000 & 2050 \\
Methane $^{2000}$ & 2050 & 2000 & 2050 & 2000 \\
\hline
\end{tabular}

a Years represent the year forcing parameter selected for each simulation.

b Anthropogenic is the RCP surface and ship emissions, BB represents the RCP biomass burning emissions, which are considered an anthropogenic impact; Biogenic is biogenic emissions calculated by MEGAN v2.1 (see text for further explanation).

${ }^{\mathrm{c}}$ Land is the human-induced land cover and land use projected by the RCP scenarios.

shot" forcing simulations are run for 9 years. We then average the results and use all years to evaluate interannual variability and ultimately define statistical significance. We replicate these simulations for the RCP4.5 and RCP8.5 scenarios.

\subsection{Model evaluation}

The CESM simulations driven by online and offline meteorology have been extensively evaluated by comparison with satellite, sonde, aircraft and ground observations of key pollutants on a global scale (Lamarque et al., 2012). Here we focus our evaluation on annual $\mathrm{PM}_{2.5}$ and $\mathrm{O}_{3}$ over the United States and use long-term means from the Interagency Monitoring of Protected Visual Environments (IMPROVE) and the Clean Air Status and Trends Network (CASTNET) data sets. Both networks monitor air quality in rural areas at the surface all year round. We calculate long-term means from observations in 90 sites for CASTNET (1995-2005), and 194 sites for IMPROVE (1998-2010). Figure 2 compares observed and simulated surface $\mathrm{O}_{3}$ and $\mathrm{PM}_{2.5}$. For $\mathrm{O}_{3}$, we use the metric for the US EPA air quality standard of daily maximum $8 \mathrm{~h}$ average (MDA-8); for $\mathrm{PM}_{2.5}$, we focus on the 

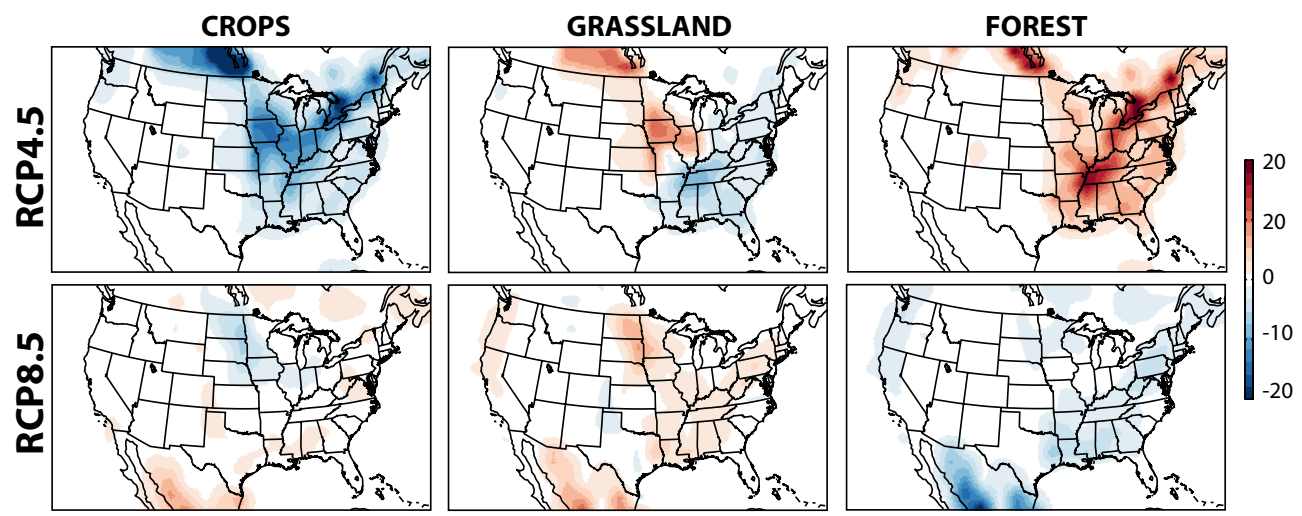

Figure 1. Projected 2050-2000 changes (\%) in forests, grasslands and croplands by the RCP4.5 and RCP8.5 scenarios.

a)

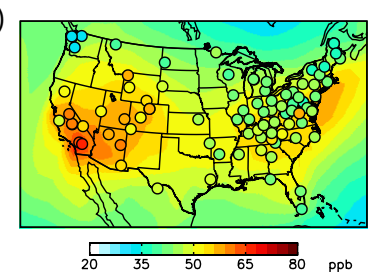

b)

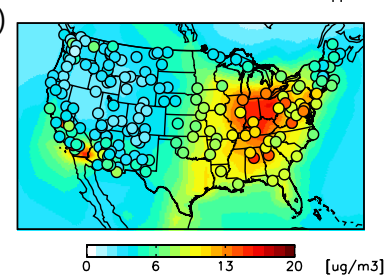

c)

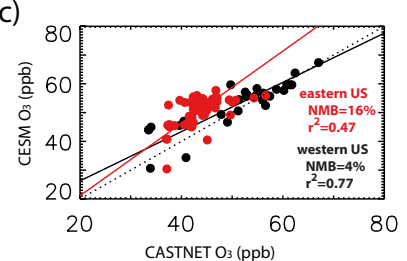

d)

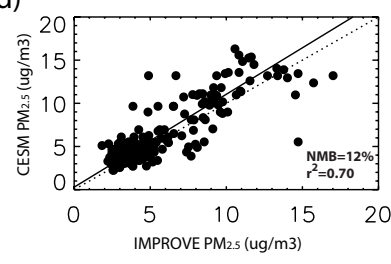

Figure 2. Simulated and observed present-day surface MDA-8 $\mathrm{O}_{3}$ and $\mathrm{PM}_{2.5}$ (a, b) and the scatter plots with modeled and observed values at the individual sites (c, d). Observations are long-term means from the CASTNET (1995-2005) and IMPROVE (19982010) networks. The squared-correlation coefficients $\left(r^{2}\right)$ and normalized mean biases (NMB) are shown in the inset. Reduced majoraxis-regression lines (solid) and the 1:1 lines (dashed) are also shown. Maps show interpolated contours from the $1.9 \times 2.5^{\circ}$ horizontal resolution output.

annual average and determine $\mathrm{PM}_{2.5}$ fine mass as the sum of $\mathrm{SO}_{4}, \mathrm{NH}_{4} \mathrm{NO}_{3}$, organic aerosol (OA), $\mathrm{BC}$, fine dust and sea salt. We compute $\mathrm{OA}$ assuming an average molecular weight of 2.0 per carbon weight for organic carbon (Malm and Hand, 2007). Organic carbon includes SOA. We summarize the comparison between the model and observations using the squared-correlation coefficient $\left(r^{2}\right)$ and the normalized mean bias (NMB) (Fig. 2c, d). In Fig. 2c, we divide the $\mathrm{O}_{3}$ comparison into eastern and western US because of the different chemical regimes (e.g., Murazaki and Hess, 2006; Lamarque et al., 2012). For $\mathrm{O}_{3}$, we find that simulated surface concentrations show good agreement with the mean observations over the western US $\left(r^{2}=0.77 ; \mathrm{NMB}=4 \%\right)$ but slightly overestimate $\mathrm{O}_{3}\left(r^{2}=0.47 ; \mathrm{NMB}=16 \%\right)$ over the eastern

US. This annual overestimation is due to a positive bias in summertime $\mathrm{O}_{3}$ (about $10 \mathrm{ppb}$ ), which is a well-known issue and has been previously documented in CESM (Lamarque et al., 2012) as well as other global and regional models (e.g., Murazaki and Hess, 2006; Fiore et al., 2009; Lapina et al., 2014). Using the optimized dry deposition scheme (Sect. 2.1), we significantly improve the simulation of summertime surface $\mathrm{O}_{3}$, which has a $30 \mathrm{ppb}$ bias $(\mathrm{NMB}=60 \%)$ over the eastern US in the standard dry deposition scheme (Val Martin et al., 2014).

We also evaluate the secondary metric W126 established to protect ecosystems and crops. The W126 is a biologically based index that estimates a cumulative ozone exposure over a 3-month growing season and applies sigmoidal weighting to hourly ozone concentrations (e.g., Lefohn et al., 1988; Lapina et al., 2014). The spatial distribution of W126 (not shown) is similar to the daily MDA- $8 \mathrm{O}_{3}$ (Fig. 2a) but exhibits larger values over regions of low and high ozone with more emphasis due to the sigmoidal weighting of the W126 function as discussed in Lapina et al. (2014). We find that the model captures the spatial distribution of W126 across the US $\left(r^{2}=0.70\right)$. However, the model tends to overestimate the magnitude by a factor of 3 , in particular over the eastern United States. In previous studies, the lower performance of model simulations of W126 compared to those of daily MDA- $8 \mathrm{O}_{3}$ has been attributed to the unbalanced sensitivity to model errors at the high end of the ozone concentration range (e.g., Tong et al., 2009; Hollaway et al., 2012; Lapina et al., 2014). For example, Lapina et al. (2014) report an overestimation of a factor varying between 2 and 4 over the United States in three chemical transport models.

For $\mathrm{PM}_{2.5}$, we find that annual levels are well represented by CESM $\left(r^{2}=0.70\right.$ and $\mathrm{NMB}=12 \%$; Fig. $\left.2 \mathrm{~d}\right)$. We further compare the simulated speciated $\mathrm{PM}_{2.5}$ with observations in Fig. 3. In our simulations, $\mathrm{SO}_{4}$ and $\mathrm{NH}_{4} \mathrm{NO}_{3}$ are overestimated, whereas $\mathrm{OA}$ is underestimated. $\mathrm{BC}$, dust and sea salt concentrations show good agreement with the mean observations, although with some scatter in the relationship $\left(r^{2}<0.40\right.$; not shown). These results are consistent with pre- 


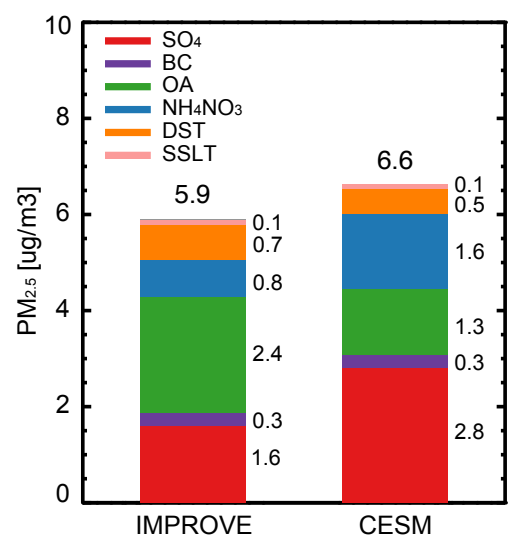

Figure 3. Simulated and observed $\mathrm{PM}_{2.5}$ chemical species over the United States. Big numerals indicate the annual $\mathrm{PM}_{2.5}$ concentrations, whereas small numerals indicate $\mathrm{PM}_{2.5}$ chemical species concentrations.

vious comparisons over the US (Lamarque et al., 2012; Albani et al., 2014).

It is important to note that in our analysis we mainly concentrate in differences between present-day and future simulations, minimizing the impact of model biases.

\subsection{Studied locations}

We focus our analysis on the national parks and wilderness areas located in the continental United States as shown in Fig. 4. We consider the 352 units designated by the US National Park Service in the lower 48 states, of which 46 are classified as protected parks and the remaining as monuments, reserves, historical parks and sites and recreational areas. Additionally, we include 109 Class I areas in the lower 48 states that are not classified as national park units, but in which air quality is also given special protection. In this work, we present results clustering the NPs and wilderness areas in six climatic regions (i.e., Northeast, Southeast, Midsouth, Southwest, West and Great Plains) (Hand et al., 2012). We define these regions and highlight the protected parks in Fig. 4.

\section{Future changes in meteorological and chemical drivers}

Climate and land cover and land use changes affect air pollution through changes in chemistry, transport, removal and natural emissions (e.g., Heald et al., 2008; Tai et al., 2012; Fiore et al., 2012). We examine here how some meteorological and chemical drivers are predicted to change in the future. Figure 5 shows present-day conditions and 2050-2000 changes in surface temperature, precipitation, boundary layer (BL) depth, isoprene emissions and $\mathrm{O}_{3}$ dry deposition velocity. We only show changes predicted by the RCP4.5 scenario

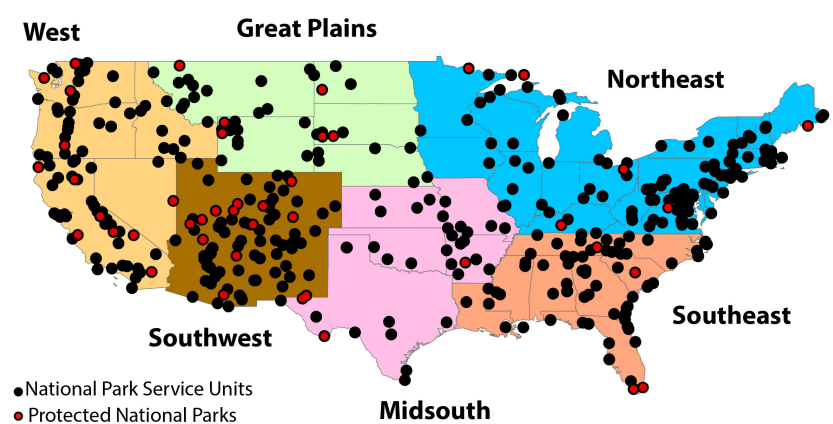

Figure 4. Location of the US national park units and wilderness areas used in this study. The US protected national parks are highlighted in red; the six US climatic regions are also identified.

since the RCP4.5 and RCP8.5 scenarios have similar climates; however, the RCP4.5 scenario has a more pronounced increase in isoprene emissions due to land use and climate change. Ozone deposition velocities also differ between the RCP4.5 and RCP8.5 simulations due to differences in projected land use change (Fig. 1). To evaluate the statistical significance of our results, we use the Student $t$ test for a $95 \%$ confidence level and highlight the regions which are significant. Previous studies have investigated in detail the sensitivity of surface $\mathrm{O}_{3}$ (e.g., Murazaki and Hess, 2006; Leung and Gustafson, 2005) and $\mathrm{PM}_{2.5}$ (e.g., Tai et al., 2012; Leibensperger et al., 2012) to numerous climatic variables. In this work, we do not intend to assess the impact that each climatic variable has on the total change in $\mathrm{PM}_{2.5}$ and surface $\mathrm{O}_{3}$. Instead, we provide here an overview on how these drivers may impact our simulated $\mathrm{O}_{3}$ and $\mathrm{PM}_{2.5}$.

Surface temperature is predicted to increase by an average of $1.7^{\circ} \mathrm{C}$ across the US due to the rising greenhouse gases in the RCP 4.5 scenario (Fig. 5a). The extent of this increase varies across the US, with a maximum increase of $4{ }^{\circ} \mathrm{C} \mathrm{ob}$ served over the central United States. The RCP8.5 scenario predicts a similar increase to the RCP4.5 scenario: $2.0^{\circ} \mathrm{C}$. We find that the 9-year simulations generate robust increases in surface temperature changes across most of the continental United States. Previous studies have reported similar results with distributions and magnitudes differing slightly depending on the model, resolution and the climate scenario considered (e.g., Murazaki and Hess, 2006; Kelly et al., 2012; Pfister et al., 2014). It is known that high ozone levels correlate well with temperature in many polluted regions due to the connection between temperature and stagnation conditions, enhanced photochemistry and biogenic and wildfire emissions (Fiore et al., 2012, and references therein). $\mathrm{PM}_{2.5}$ is also affected by many of the same meteorological processes as surface $\mathrm{O}_{3}$, although the relationship is more complex and the sign of the effect can be positive or negative because of the different sensitivities of the $\mathrm{PM}_{2.5}$ chemical species (e.g., Tai et al., 2012). Thus, our simulated increase in temperature 
Table 4. Simulated annual air quality over the US national parks and wilderness areas ${ }^{\mathrm{a}}$.

\begin{tabular}{|c|c|c|c|c|c|c|c|c|c|}
\hline \multirow[b]{3}{*}{ National park } & \multicolumn{3}{|c|}{$\mathrm{PM}_{2.5}\left(\mu \mathrm{g} \mathrm{m}^{-3}\right)$} & \multicolumn{3}{|c|}{ MDA-8 $\mathrm{O}_{3}(\mathrm{ppb})$} & \multicolumn{3}{|c|}{$\mathrm{W} 126 \mathrm{O}_{3}\left(\mathrm{ppm} \mathrm{h}^{-1}\right)$} \\
\hline & 2000 & 2050 & 2050 & 2000 & 2050 & 2050 & 2000 & 2050 & 2050 \\
\hline & Base & $\mathrm{RCP} 4.5$ & RCP8.5 & Base & $\mathrm{RCP} 4.5$ & RCP8.5 & Base & $\mathrm{RCP} 4.5$ & RCP8.5 \\
\hline Arches, UT $\left(39^{\circ} \mathrm{N}, 110^{\circ} \mathrm{W}\right)$ & 3.2 & 1.6 & 2.6 & 57.8 & 51.2 & 60.8 & 39.9 & 10.4 & 39.1 \\
\hline Badlands, SD $\left(44^{\circ} \mathrm{N}, 102^{\circ} \mathrm{W}\right)$ & 4.1 & 1.7 & 3.1 & 49.4 & 47.8 & 55.1 & 15.9 & 11.5 & 29.2 \\
\hline Big Bend, TX $\left(29^{\circ} \mathrm{N}, 103^{\circ} \mathrm{W}\right)$ & 5.2 & 2.9 & 3.8 & 47.0 & 42.9 & 49.4 & 5.9 & 2.9 & 8.5 \\
\hline Bryce Canyon, UT $\left(38^{\circ} \mathrm{N}, 112^{\circ} \mathrm{W}\right)$ & 4.1 & 2.1 & 3.2 & 58.7 & 51.7 & 59.7 & 45.8 & 12.1 & 33.3 \\
\hline Canyonlands, UT $\left(38^{\circ} \mathrm{N}, 110^{\circ} \mathrm{W}\right)$ & 3.2 & 1.6 & 2.6 & 57.8 & 51.2 & 60.8 & 39.9 & 10.4 & 39.1 \\
\hline Capitol Reef, UT $\left(38^{\circ} \mathrm{N}, 111^{\circ} \mathrm{W}\right)$ & 3.2 & 1.6 & 2.6 & 57.8 & 51.2 & 60.8 & 39.9 & 10.4 & 39.1 \\
\hline Carlsbad Caverns, $\mathrm{NM}\left(32^{\circ} \mathrm{N}, 104^{\circ} \mathrm{W}\right)$ & 5.0 & 2.6 & 3.2 & 50.7 & 45.5 & 52.3 & 13.4 & 4.9 & 13.1 \\
\hline Channel Islands, $\mathrm{CA}\left(34^{\circ} \mathrm{N}, 119^{\circ} \mathrm{W}\right)$ & 8.6 & 6.2 & 5.6 & 52.4 & 50.2 & 55.5 & 12.2 & 4.6 & 9.6 \\
\hline Dry Tortugas, FL $\left(25^{\circ} \mathrm{N}, 83^{\circ} \mathrm{W}\right)$ & 6.0 & 4.2 & 4.0 & 40.8 & 38.4 & 44.6 & 0.6 & 0.5 & 1.2 \\
\hline Everglades, FL $\left(25^{\circ} \mathrm{N}, 81^{\circ} \mathrm{W}\right)$ & 5.9 & 3.9 & 3.3 & 45.7 & 40.4 & 45.6 & 1.1 & 0.5 & 1.0 \\
\hline Glacier, MT $\left(49^{\circ} \mathrm{N}, 114^{\circ} \mathrm{W}\right)$ & 3.1 & 2.6 & 2.5 & 48.5 & 46.8 & 52.7 & 9.5 & 4.2 & 9.7 \\
\hline Grand Canyon, $\mathrm{AZ}\left(36^{\circ} \mathrm{N}, 113^{\circ} \mathrm{W}\right)$ & 4.1 & 2.1 & 3.2 & 58.7 & 51.7 & 59.7 & 45.8 & 12.1 & 33.3 \\
\hline Grand Teton, WY $\left(44^{\circ} \mathrm{N}, 111^{\circ} \mathrm{W}\right)$ & 2.2 & 1.4 & 1.8 & 53.8 & 50.8 & 58.2 & 18.1 & 8.3 & 22.8 \\
\hline Great Basin, NV $\left(39^{\circ} \mathrm{N}, 114^{\circ} \mathrm{W}\right)$ & 2.5 & 1.5 & 1.7 & 57.0 & 51.6 & 59.0 & 34.7 & 11.5 & 28.2 \\
\hline Great Sand Dunes, $\mathrm{CO}\left(38^{\circ} \mathrm{N}, 105^{\circ} \mathrm{W}\right)$ & 4.2 & 2.0 & 3.3 & 55.9 & 49.7 & 59.1 & 29.7 & 8.5 & 32.1 \\
\hline $\begin{array}{l}\text { Great Smoky Mountains, } \\
\mathrm{NC}, \mathrm{TN}\left(36^{\circ} \mathrm{N}, 83^{\circ} \mathrm{W}\right)\end{array}$ & 10.9 & 5.6 & 4.2 & 55.7 & 46.4 & 51.8 & 43.8 & 5.7 & 14.9 \\
\hline Guadalupe Mountains, $\mathrm{TX}\left(32^{\circ} \mathrm{N}, 105^{\circ} \mathrm{W}\right)$ & 5.0 & 2.6 & 3.2 & 50.7 & 45.5 & 52.3 & 13.4 & 4.9 & 13.1 \\
\hline Hot Springs, AR $\left(34^{\circ} \mathrm{N}, 93^{\circ} \mathrm{W}\right)$ & 10.8 & 4.7 & 5.5 & 53.0 & 43.9 & 51.0 & 32.0 & 3.9 & 13.3 \\
\hline North Cascades, WA $\left(49^{\circ} \mathrm{N}, 121^{\circ} \mathrm{W}\right)$ & 4.9 & 3.2 & 2.4 & 45.2 & 43.3 & 47.7 & 6.3 & 1.2 & 1.9 \\
\hline Olympic, WA $\left(48^{\circ} \mathrm{N}, 123^{\circ} \mathrm{W}\right)$ & 4.9 & 3.2 & 2.4 & 45.2 & 43.3 & 47.7 & 6.3 & 1.2 & 1.9 \\
\hline Petrified Forest, $\mathrm{AZ}\left(35^{\circ} \mathrm{N}, 110^{\circ} \mathrm{W}\right)$ & 5.5 & 2.6 & 4.4 & 58.2 & 50.3 & 59.3 & 44.0 & 10.2 & 34.6 \\
\hline Redwood, CA $\left(41^{\circ} \mathrm{N}, 124^{\circ} \mathrm{W}\right)$ & 3.4 & 3.4 & 2.6 & 44.9 & 44.4 & 49.5 & 1.2 & 0.8 & 1.4 \\
\hline Rocky Mountain, $\mathrm{CO}\left(40^{\circ} \mathrm{N}, 106^{\circ} \mathrm{W}\right)$ & 4.6 & 2.0 & 3.1 & 56.8 & 51.8 & 60.0 & 37.9 & 13.6 & 36.4 \\
\hline Saguaro, $\mathrm{AZ}\left(32^{\circ} \mathrm{N}, 110^{\circ} \mathrm{W}\right)$ & 6.1 & 3.3 & 4.3 & 57.8 & 49.6 & 56.3 & 45.0 & 10.0 & 23.0 \\
\hline Sequoia, CA $\left(36^{\circ} \mathrm{N}, 119^{\circ} \mathrm{W}\right)$ & 3.4 & 2.1 & 2.1 & 58.9 & 52.7 & 58.9 & 45.5 & 15.1 & 28.3 \\
\hline Shenandoah, VA $\left(38^{\circ} \mathrm{N}, 78^{\circ} \mathrm{W}\right)$ & 13.2 & 6.2 & 4.0 & 57.0 & 49.0 & 51.7 & 66.5 & 11.7 & 13.3 \\
\hline Theodore Roosevelt, ND $\left(47^{\circ} \mathrm{N}, 103^{\circ} \mathrm{W}\right)$ & 4.8 & 1.8 & 3.6 & 47.8 & 46.8 & 53.6 & 16.2 & 11.0 & 29.3 \\
\hline Voyageurs, $\mathrm{MN}\left(48^{\circ} \mathrm{N}, 93^{\circ} \mathrm{W}\right)$ & 4.1 & 2.3 & 3.2 & 43.5 & 42.9 & 48.0 & 5.7 & 3.0 & 7.4 \\
\hline Wind Cave, SD $\left(44^{\circ} \mathrm{N}, 103^{\circ} \mathrm{W}\right)$ & 4.1 & 1.7 & 3.1 & 49.4 & 47.8 & 55.1 & 15.9 & 11.5 & 29.2 \\
\hline Yellowstone, WY, MT, ID $\left(45^{\circ} \mathrm{N}, 110^{\circ} \mathrm{W}\right)$ & 2.2 & 1.4 & 1.8 & 53.8 & 50.8 & 58.2 & 18.1 & 8.3 & 22.8 \\
\hline Yosemite, $\mathrm{CA}\left(38^{\circ} \mathrm{N}, 119^{\circ} \mathrm{W}\right)$ & 5.5 & 3.3 & 2.7 & 60.1 & 52.8 & 58.5 & 60.4 & 18.9 & 29.1 \\
\hline Zion, UT $\left(37^{\circ} \mathrm{N}, 113^{\circ} \mathrm{W}\right)$ & 4.1 & 2.1 & 3.2 & 58.7 & 51.7 & 59.7 & 45.8 & 12.1 & 33.3 \\
\hline
\end{tabular}

${ }^{a}$ Shown only results for the 46 protected national parks located in the continental United States; results from other NPs and wilderness areas can be provided by request. 

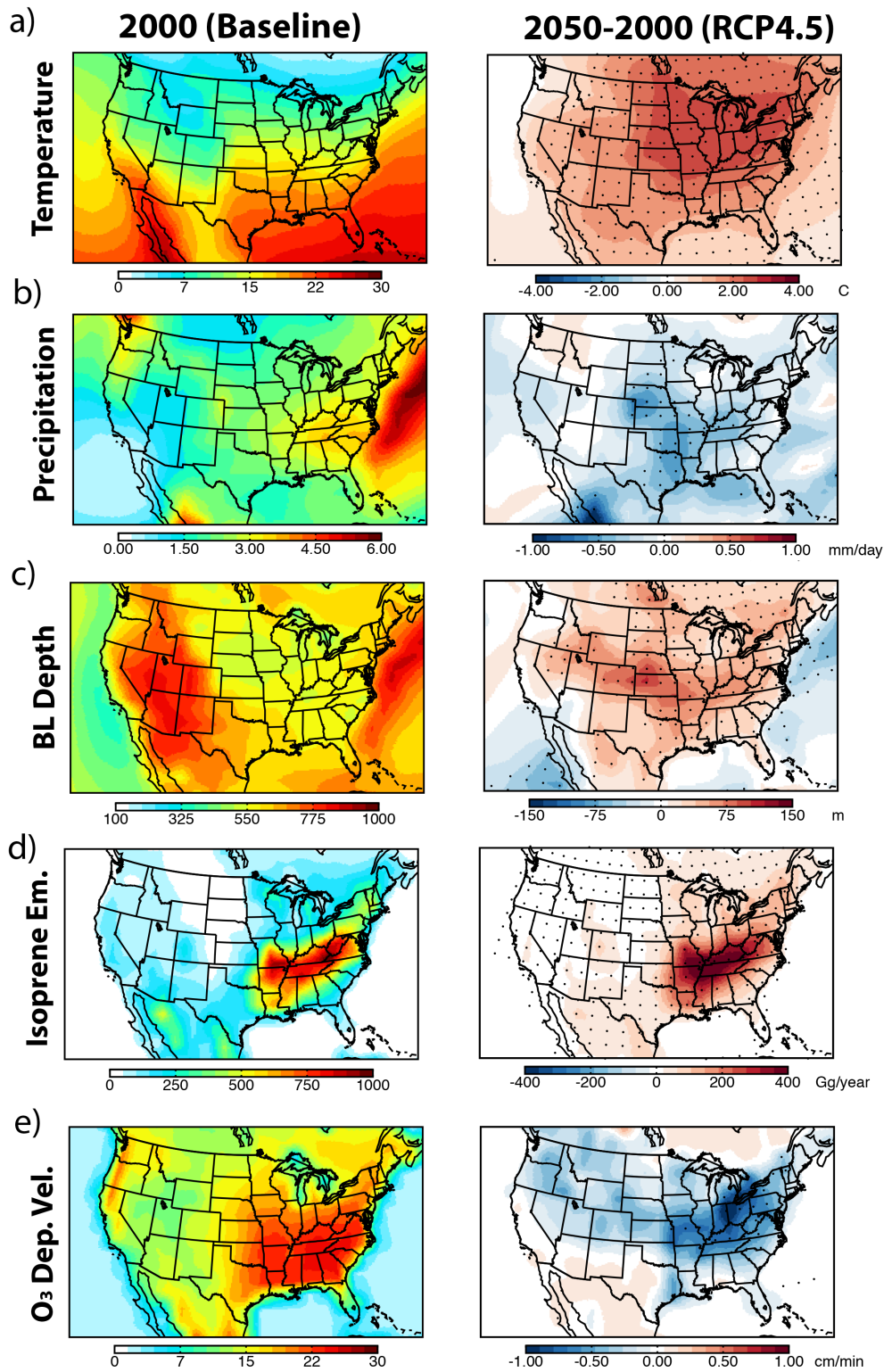

Figure 5. Simulated annual average present-day (left) and projected 2050-2000 changes (right) for surface temperature (a), precipitation (b), boundary layer depth (c), isoprene emissions (d) and $\mathrm{O}_{3}$ dry deposition velocity (e). All maps show changes predicted by the RCP4.5 as a result of the combination of climate, land use and emission changes, except for the $\mathrm{O}_{3}$ dry deposition velocity that shows only the changes from land use. Regions with changes that are significant at the $95 \%$ confidence level are indicated in the maps with dots, and maps show interpolated contours from the $1.9 \times 2.5^{\circ}$ horizontal resolution output.

will intensify surface $\mathrm{O}_{3}$ and most probably $\mathrm{PM}_{2.5}$ pollution over the United States.

Air quality is also sensitive to precipitation and cloud cover. For example, $\mathrm{PM}_{2.5}$ is expected to decrease in regions with increased precipitation (e.g., Pye et al., 2009; Racherla and Adams, 2008). In our simulations, precipitation decreases over most of the continental US (30\%), with some small increases over some regions in the northwestern US ( $8 \%)$ (Fig. 5b). However, not all of the changes in precipitation are significant and the absolute changes are generally small $\left(<1 \mathrm{~mm} \mathrm{day}^{-1}\right)$ despite the large percentage change. We find a similar pattern in the cloud cover (not shown). A decrease in cloudiness is associated with an increase in solar radiation, which favors surface $\mathrm{O}_{3}$ production in our simulations.

An important meteorological process for diluting and transporting air pollutants is mixing within the boundary layer. In our simulations, the boundary layer depth across the US is predicted to generally increase, with the largest increase over the central US (>100 m; about $20 \%$ ) (Fig. 5c). 
The increases in BL depth favors ventilation and reduces pollutant accumulation. In our simulations, we notice that BL depth increases (i.e., favoring low $\mathrm{PM}_{2.5}$ and $\mathrm{O}_{3}$ concentrations) and precipitation (and cloud cover) decreases (i.e., favoring high $\mathrm{PM}_{2.5}$ and $\mathrm{O}_{3}$ concentrations) are generally colocated. These two processes have opposite effects on air quality and this highlights the challenges in predicting possible air quality impacts resulting from climate change.

Higher temperature and solar radiation will also affect biogenic emissions, which in turn will influence $\mathrm{PM}_{2.5}$ and surface $\mathrm{O}_{3}$. Biogenic emissions will also depend on land use changes. In 2050, isoprene emissions are predicted to increase from 28 to $43 \mathrm{TgC}$ (about $53 \%$ ) in the US (Table 2), with $10 \%$ of this increase driven by land use changes. This effect is more significant in the southeastern US (about $25 \%$ ) due to afforestation (Fig. 5d). The RCP8.5 scenario also predicts an increase in biogenic emissions, but with a lower influence from land use and climate changes (33\%; not shown). We note that our isoprene emissions are slightly overestimated because we neglect the effect of $\mathrm{CO}_{2}$ inhibition, as explained in Sect. 2.1. Increased emissions of biogenic volatile organic compounds (e.g., isoprene) will increase $\mathrm{PM}_{2.5}$ through SOA formation (Heald et al., 2008). For ozone, the impact of changing biogenic emissions depends critically on the fate of isoprene nitrates, i.e., whether isoprene nitrate is a terminal or temporal sink of $\mathrm{NO}_{\mathrm{x}}$ (e.g., Horowitz et al., 2007; Wu et al., 2012). In our model, isoprene nitrate recycles $40 \%$ of $\mathrm{NO}_{\mathrm{x}}$ (Horowitz et al., 2007). Therefore, increases in biogenic emissions tend to enhance surface $\mathrm{O}_{3}$, regardless of the $\mathrm{NO}_{\mathrm{x}}$ concentrations. This $\mathrm{O}_{3}$ response to $\mathrm{NO}_{\mathrm{x}}$ with respect to changes in biogenic emissions is slightly different than other models, where isoprene nitrates represent a terminal sink of $\mathrm{NO}_{\mathrm{x}}$. In those cases, increases in isoprene emissions lead to increases or decreases in surface $\mathrm{O}_{3}$ concentrations depending on the availability of $\mathrm{NO}_{\mathrm{x}}$ (e.g., Wu et al., 2012; Mao et al., 2013).

Land use changes can also influence deposition processes. For example, large $\mathrm{O}_{3}$ dry deposition velocities are associated with denser broadleaf forests (i.e., with high LAI) and crops (e.g., Wesely, 1989; Val Martin et al., 2014), whereas grasslands and needleleaf forests (i.e., with low LAI) are characterized by low deposition velocities. In our simulations, the $\mathrm{O}_{3}$ dry deposition velocity generally shows a small decrease across the US $\left(0.2-1.0 \mathrm{~cm} \mathrm{~min}^{-1}\right.$; about $1-$ $3 \%$ ) (Fig. 5e). The RCP8.5 scenario projects more variable, but even smaller changes in the $\mathrm{O}_{3}$ dry deposition velocity $(<0.6 \%)$, associated with a less pronounced change in vegetation. Interestingly, in this study we find a reduction in the annual $\mathrm{O}_{3}$ dry deposition velocity due to the shift from croplands to grasslands and forests. This result contrasts with previous studies that report decreased dry deposition velocities in regions with increased agricultural land (Ganzeveld et al., 2010; Wu et al., 2012). However, these studies focus on either summertime changes when broadleaf forests have a larger dry deposition velocity than crops (Wu et al., 2012) or use a different dry deposition parameterization (Ganzeveld et al., 2010). We note that the resulting changes in the deposition velocities in our model are not significant at the $95 \%$ confidence level and these two previous studies do not evaluate the statistical significance of their results. Nonetheless, this comparison underlines the important effect that land use change assumptions may have on the projections of future air quality.

\section{Future $\mathrm{PM}_{2.5}$ air quality}

In this section, we first examine how total and speciated $\mathrm{PM}_{2.5}$ are predicted to change in the future due to climate, emissions and land use changes. We then discuss the impacts of future climate-driven wildfire activity in $\mathrm{PM}_{2.5}$ and haze.

\subsection{Regional annual changes in $\mathbf{P M}_{2.5}$}

Figure 6 shows changes in annual surface $\mathrm{PM}_{2.5}$ concentrations following the RCP4.5 and RCP8.5 scenarios over the continental United States. The projected changes in 2050 from the combined effects and the individual effects of emissions, climate and land use change are also shown. The "emissions" simulation takes into account changes in anthropogenic and biomass burning emissions and methane levels; the "land use" simulation is associated with changes in climate-driven biogenic emissions and land cover. We also indicate the regions with confidence levels higher than $95 \%$ from the Student $t$ test; we find that the 9-year simulations generate robust results across most of the continental US for the simulations with the combined effects and emissions alone.

The combined effects of changing climate, land use, and emissions lead to a strong decrease in $\mathrm{PM}_{2.5}$ concentrations across the continental US (Fig. 6a), with an average projected decrease of about $4 \mu \mathrm{g} \mathrm{m}^{-3}(\sim 50 \%)$ for both the RCP4.5 and RCP8.5 scenarios. The absolute decrease is stronger in the eastern than in the western US, about $4 \mu \mathrm{g} \mathrm{m}^{-3}$ versus $2 \mu \mathrm{g} \mathrm{m}^{-3}$, because the eastern US is characterized by larger $\mathrm{PM}_{2.5}$ concentrations (Fig. 2b). Projected changes in US $\mathrm{PM}_{2.5}$ for 2050 largely reflect changes in anthropogenic emissions, which drive the majority ( $>95 \%$ ) of this decrease all over the United States. The contribution of climate and land use changes, although minor and rather insignificant in most of the US, may counteract the benefits of emission reductions in some regions (Fig. 6b). For example, the RCP4.5 scenario projects a $47 \%$ total average decrease in $\mathrm{PM}_{2.5}$ in the Southwest region, with about $52 \%$ drop due to emission reductions but a counter veiling increase of 5 and $0.1 \%$ from climate and land use, respectively. In many regions the impact of climate or land use change is not significant compared to climate variability when averaging over 9 years.

To examine in more detail future changes in $\mathrm{PM}_{2.5}$ we show changes in speciated $\mathrm{PM}_{2.5}$ in Fig. 7 . We find that 
a)
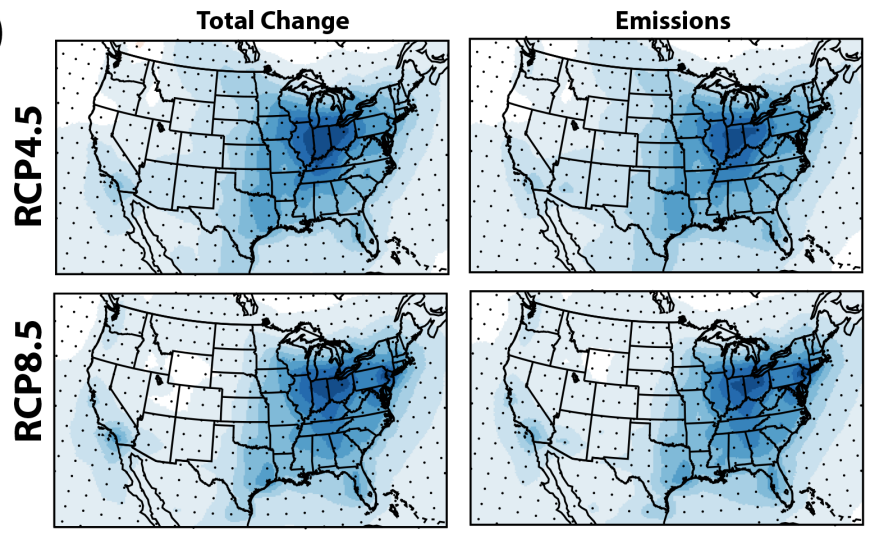

$\mathrm{ug} / \mathrm{m}^{3}$

b)

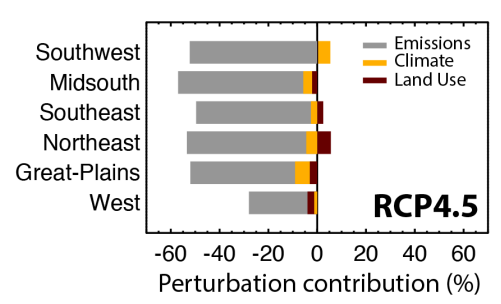

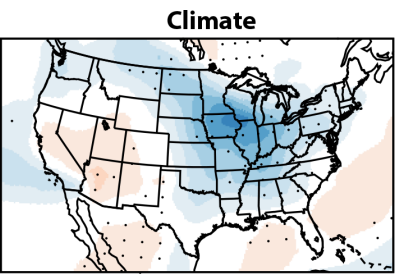
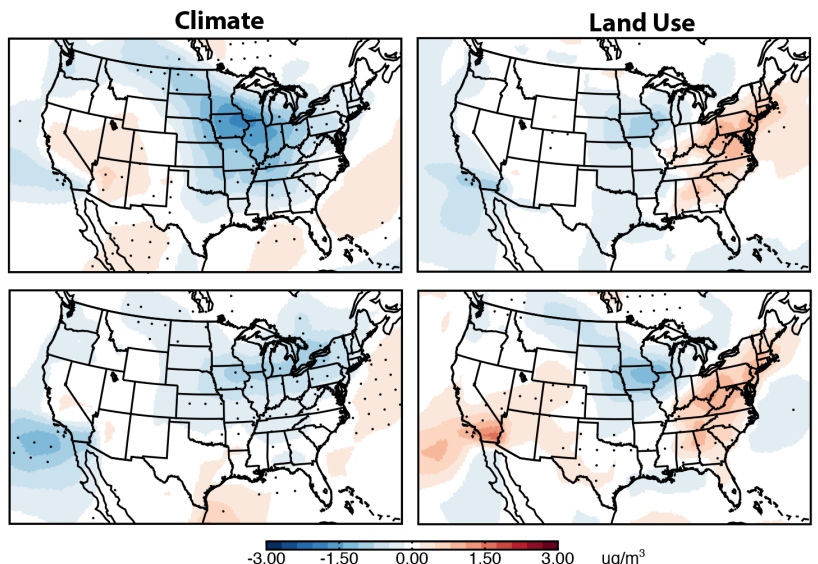

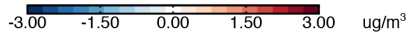

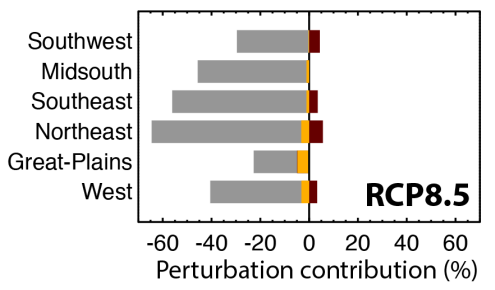

Figure 6. Projected simulated 2050-2000 changes in annual $\mathrm{PM}_{2.5}$ as a result of the combination of climate, land use and emission changes, and the individual changes (a) and the percentage contribution of the individual perturbation (b) for the RCP4.5 and RCP8.5 scenarios. Regions with changes that are significant at the $95 \%$ confidence level are indicated in the maps with dots, and maps show interpolated contours from the $1.9 \times 2.5^{\circ}$ horizontal resolution output. Bars represent the changes $(\%)$ for each individual forcing, i.e., emissions and methane levels (gray), climate (yellow) and land use (dark red).

the decrease in $\mathrm{PM}_{2.5}$ concentrations is mainly driven by decreases in $\mathrm{SO}_{4}$ and, to a lesser extent, in $\mathrm{NH}_{4} \mathrm{NO}_{3}$ and BC. Under the RCP4.5 and RCP8.5 scenarios, anthropogenic $\mathrm{SO}_{2}$ emissions are projected to decrease substantially in the western and the eastern US compared to present-day (84 and $89 \%$ in RCP4.5 and 69 and $90 \%$ in RCP8.5, respectively; Table 2). Large decreases in $\mathrm{NO}_{\mathrm{x}}$ emissions are also projected (75 and $78 \%$ in RCP4.5 and 50 and $72 \%$ in RCP8.5) whereas $\mathrm{NH}_{3}$ emissions increase (33 and $25 \%$ in RCP4.5 and 59 and $44 \%$ in RCP8.5). The largest significant change in $\mathrm{PM}_{2.5}$ is projected with the RCP8.5 scenario over the Northeast region, with a decrease of $90 \%$ in BC, $79 \%$ in $\mathrm{SO}_{4}$ and $46 \%$ in $\mathrm{NH}_{4} \mathrm{NO}_{3}$. Organic aerosol increases slightly, in particular over the Northeast, Southeast and West regions. This increase does not offset the decreases in the other species, yet it can be important in some regions. Over the Southeast, the RCP4.5 and RCP8.5 scenarios project similar decreases in $\mathrm{SO}_{4}, \mathrm{NH}_{4} \mathrm{NO}_{3}$ and $\mathrm{BC}$. However, $\mathrm{PM}_{2.5}$ concentrations are predicted to be lower in the RCP8.5 than in the RCP4.5 scenario because of the relative importance of $\mathrm{OA}$ in the total $\mathrm{PM}_{2.5}$ loading. Higher OA concentrations in the RCP4.5 scenarios result from higher VOC emissions (Table 2) associated with reforestation and climate change, as discussed in Sect. 3.

Our results are consistent with previous studies, which have shown the small impact of climate change on $\mathrm{PM}_{2.5}$ lev- els and the significant contribution from projected emission reductions (e.g., Tagaris et al., 2007; Pye et al., 2009; Lam et al., 2011; Kelly et al., 2012). Comparing $\mathrm{PM}_{2.5}$ projections from different studies is not straightforward due to variations in the study region, reported $\mathrm{PM}_{2.5}$ metrics and use of different climate and emissions (Fiore et al., 2012). A decrease of about $2 \mu \mathrm{g} \mathrm{m}^{-3}(25 \%)$ over the US was projected for the SRES A1B scenario by Tagaris et al. (2007) for the combined effect of climate and emissions, with the bulk of this decrease resulting from sulfate, nitrate and ammonium reductions. Using the same scenario, Lam et al. (2011) found a similar decrease (4-5 $\mathrm{\mu g} \mathrm{m}^{-3}$ ), with $90 \%$ of the reduction due to emission reductions. Most recently, Kelly et al. (2012) reported summertime regional decreases of more than $3 \mu \mathrm{g} \mathrm{m}^{-3}$ over the US, with the SRES A2 climate and RCP6.0 emission scenarios.

We summarize the simulated $\mathrm{PM}_{2.5}$ changes over the US NP and wilderness areas in Table 4. We show results for the 46 protected national parks located in the continental United States. We find that the RCP4.5 and RCP8.5 scenarios predict a significant reduction of $\mathrm{PM}_{2.5}$ levels across the protected NPs, with the exception of the Crater Lake and Lassen Volcanic NPs. In these two NPs, the RCP8.5 scenario projects a slight increase in annual $\mathrm{PM}_{2.5}$, but concentrations are predicted to remain below $12 \mu \mathrm{g} \mathrm{m}^{-3}$, the primary annual US National Ambient Air Quality Standards (NAAQS) for 



Figure 7. Annual $\mathrm{PM}_{2.5}$ chemical species for present-day and 2050 as predicted by the RCP 4.5 and RCP 8.5 scenarios in the US climatic regions. The inset maps show the states in the region in gray, and the numerals indicate the numbers of US national parks and wilderness areas in each climatic region. Big numerals indicate the annual $\mathrm{PM}_{2.5}$ concentrations.

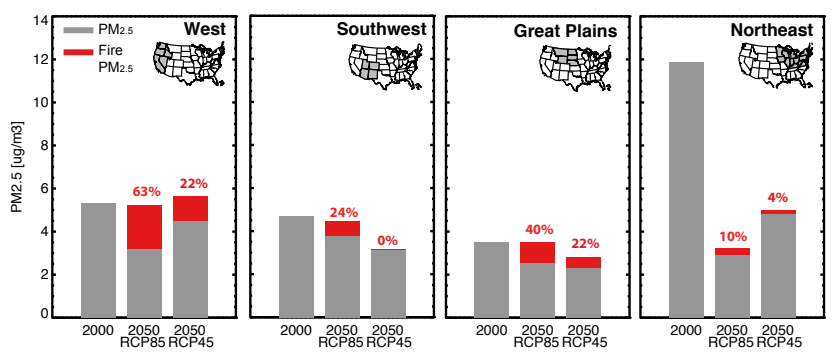

Figure 8. Changes in $\mathrm{PM}_{2.5}$ resulting from climate-driven fire activity in the US regions affected by fire. Simulated $\mathrm{PM}_{2.5}$ by the $\mathrm{RCP}$ scenarios is shown in gray and future $\mathrm{PM}_{2.5}$ from climatedriven fire emissions in red. The inset maps show the states in the region in gray and the red numerals indicate the percentage change in $\mathrm{PM}_{2.5}$ when climate-driven fire activity is included in the simulation.

$\mathrm{PM}_{2.5}$. In the Joshua Tree NP, both RCP scenarios predict a significant improvement of $\mathrm{PM}_{2.5}$ air quality, but with an annual average above $12 \mu \mathrm{g} \mathrm{m}^{-3}$ due to the dominance of natural dust in this region.

It is important to note that changes in the frequency and magnitude of the fire resulting from climate change are not included in this analysis, and this effect may have an important impact on the $\mathrm{PM}_{2.5}$ levels associated with climate change, as discussed in the following section.

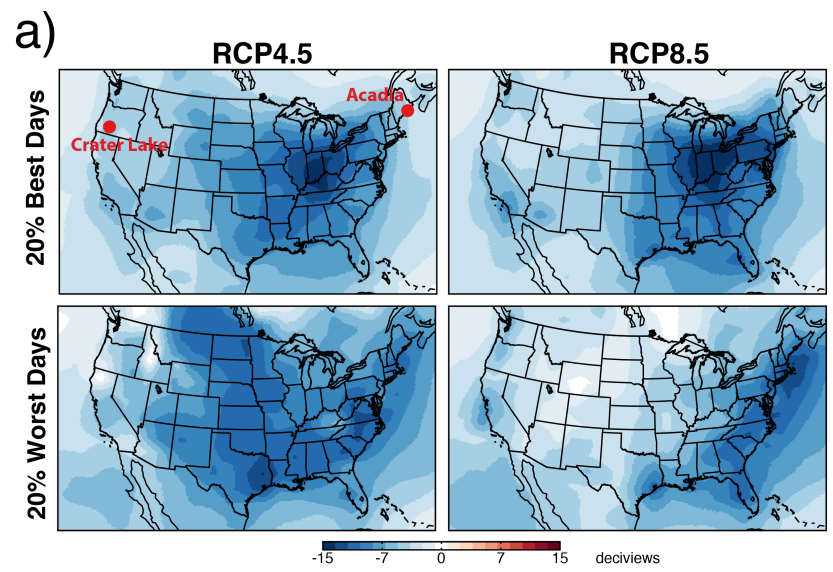

b)
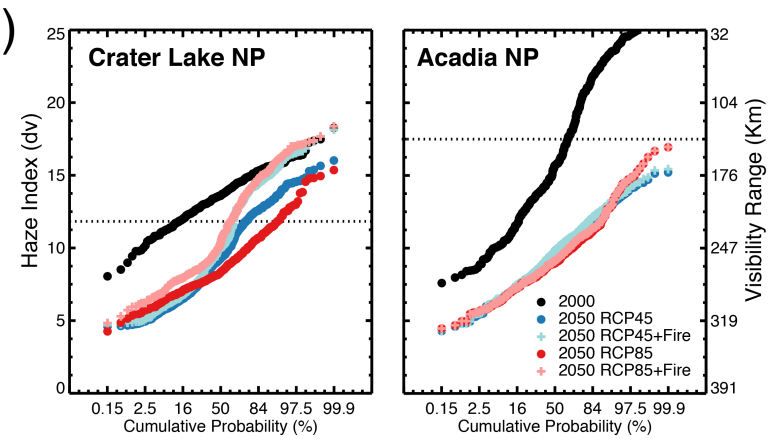

Figure 9. Projected simulated 2050-2000 changes in haze index (HI) as a result of the combination of climate, land use and emission changes (a) and the cumulative probability distributions of daily mean haze index in the Crater Lake and Acadia NPs (b). Maps show " $20 \%$ best days" as the averaged HI during the cleanest days and " $20 \%$ worst days" as averaged HI during the haziest days (see text for further explanation); data are shown as interpolated contours from the $1.9^{\circ} \times 2.5^{\circ}$ horizontal resolution output. The location of the Crater Lake and Acadia NPs are indicated in the top left map. The cumulative distribution plots show simulated daily $\mathrm{HI}$ for the present-day (black circles), 2050 projected by RCP4.5 (blue circles) and by RCP8.5 (red circles), and 2050 with the effects of climatedriven fires by RCP4.5 (light blue cross) and by RCP8.5 (light red cross). The $2050 \mathrm{HI}$ target to reach natural visibility conditions by 2064 are indicated with a horizontal dotted line.

\subsection{Effects of increased fire activity on summertime $\mathbf{P M}_{2.5}$}

Climate-driven changes in fire emissions can be an important factor controlling $\mathrm{PM}_{2.5}$ concentrations (Spracklen et al., 2009; Yue et al., 2013). Yue et al. (2013), use results from 15 climate models following the SRES A1B scenario and a fire prediction model of area burned to predict increases of $63-169 \%$ in area burned over the western US in 2050, which leads to about $150-170 \%$ increases in OC and BC fire emissions. The RCP4.5 scenario predicts an increase of about $60 \%$ in OC fire emissions over the western US, whereas the RCP8.5 projects a marginal decrease of $0.3 \%$. These two 


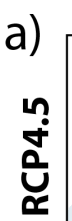
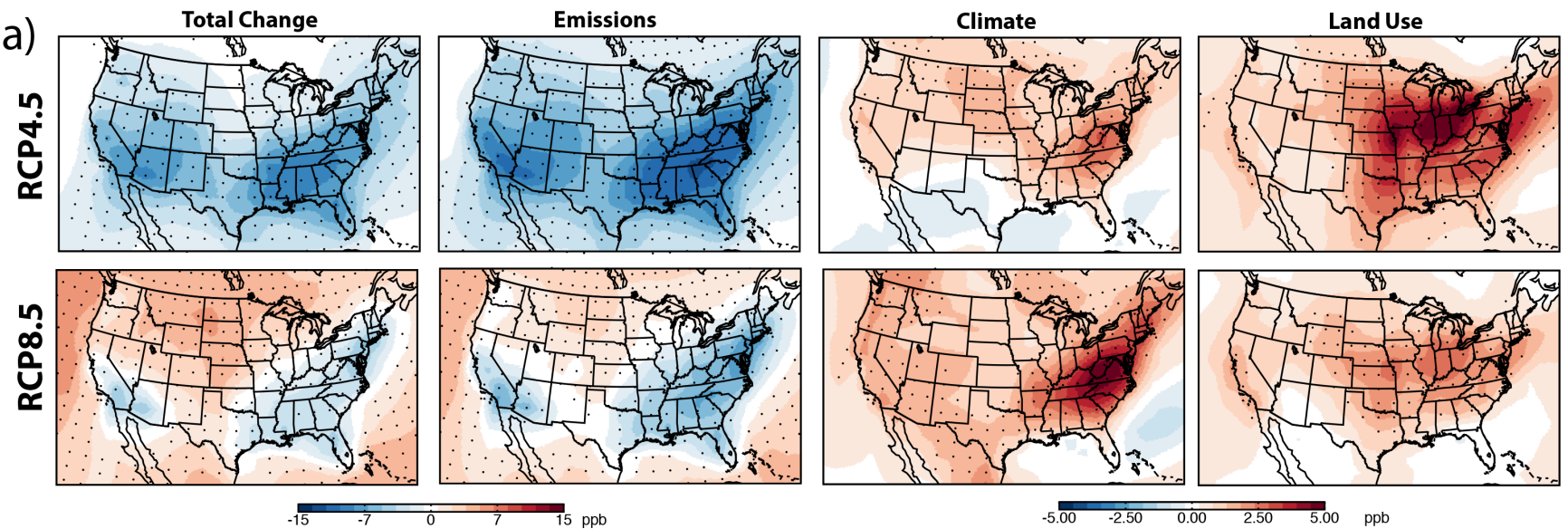

b)
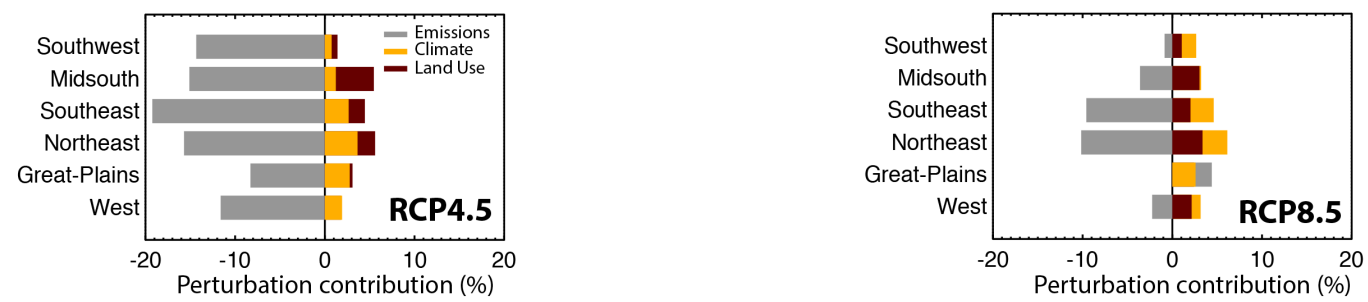

Figure 10. Projected simulated 2050-2000 changes in surface $\mathrm{O}_{3}$ as a result of the combination of climate, land use and emission changes, and the individual changes (a) and the percentage contribution of the individual perturbations (b) for the RCP4.5 and RCP8.5 scenarios. Maps show interpolated contours from the $1.9 \times 2.5^{\circ}$ horizontal resolution output. Regions with changes that are significant at the $95 \%$ confidence level are indicated in the maps with dots, and $\mathrm{O}_{3}$ concentrations are annual maximum daily $8 \mathrm{~h}$ (MDA-8) averages. Bars represent the changes $(\%)$ for each individual forcing, i.e., emissions and methane levels (gray), climate (yellow) and land use (dark red).

RCP scenarios clearly underestimate the average increase in carbonaceous aerosol fire emissions associated with climate feedbacks as projected by Yue et al. (2013).

To assess the importance of climate-driven fire emissions on future $\mathrm{PM}_{2.5}$, we perform an additional simulation (not shown in Table 3) where we increase the RCP fire emissions over the US in order to match the projections of Yue et al. (2013). In doing so, we keep the spatial distribution of fire as described by the RCP scenarios and apply a homogeneous increase on a monthly basis. We scale the RCP fire emissions over the US and Canada, with the exception of the eastern US, where fire activity is not predicted to significantly increase in the future due to climate (Scholze et al., 2006; Moritz et al., 2012).

Figure 8 shows the effect of climate-driven fire emissions on summertime $\mathrm{PM}_{2.5}$. Here we focus on the summer, which is the peak fire season in the United States. We compare the $\mathrm{PM}_{2.5}$ levels predicted by the RCP scenarios in 2050 to those when climate-driven fire activity is included and only show those climatic regions where $\mathrm{PM}_{2.5}$ is affected by fire, i.e., West, Great Plains, Southwest and Northeast. $\mathrm{PM}_{2.5}$ concentrations in these regions increase significantly as a result of increased fire activity. These increases are most prominent over the West and Great Plains regions, in which fire-driven $\mathrm{PM}_{2.5}$ may potentially offset anticipated reductions in anthropogenic emissions. For example, over the West region we estimate that fire activity may increase future summertime $\mathrm{PM}_{2.5}$ from 3.2 to $5.2 \mu \mathrm{g} \mathrm{m}^{-3}(63 \%)$ in the RCP8.5 scenario and from 4.5 to $5.6 \mu \mathrm{g} \mathrm{m}^{-3}$ (22\%) in the RCP4.5 scenario. The concentration of organic aerosol nearly doubles in both scenarios, and this dominates the total change in $\mathrm{PM}_{2.5}$. It is important to note that our fire OA may be underestimated as we do not include secondary production of OA from fire emissions. Increased fire activity may also affect $\mathrm{PM}_{2.5}$ further downwind from the fires. We estimate that summertime $\mathrm{PM}_{2.5}$ may increase up to $4-10 \%$ in the Northeast region due to smoke transported from fires in the western US and the boreal region.

Therefore, changes in summertime $\mathrm{PM}_{2.5}$ concentrations may be dominated by changes in fire activity in most of the western US in a future climate. This same fire pollution may significantly impair visibility over this region, as well as hundreds of kilometers downwind from the fire sources.

\subsection{Effects on future visibility}

We evaluate the effects of future changes in visibility in the US NP and wilderness areas across the continental US by examining changes in the haze index (HI) and visibility range. We calculate the HI based on the definition of the US EPA (2003) and the visibility range as in Pitchford and Malm (1994) using the results of the daily averages of $\mathrm{PM}_{2.5}$ chem- 

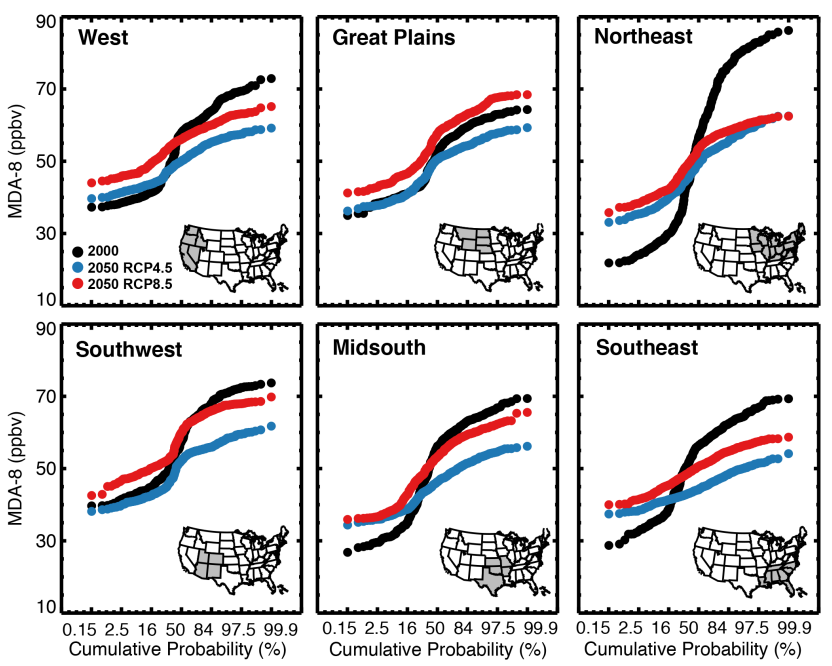

Figure 11. Cumulative probability distributions of simulated surface $\mathrm{O}_{3}$ MDA-8 averaged over the US national parks and wilderness areas in the US climatic regions, for present-day (black circles) and 2050 predicted by the RCP4.5 (blue circles) and RCP8.5 (red circles) scenarios. The inset maps show the states in the region in gray.

ical species. Figure 9a shows changes in HI for the most polluted and the cleanest episodes (i.e., worst and best days, respectively) predicted by the RCP4.5 and RCP8.5 scenarios. We define the most polluted and cleanest episodes as those days characterized by aerosol levels with the $20 \%$ worst and best visibility, that is, with the HI above the 90th percentile or below the 10th percentile, respectively (US EPA, 2003). As an example, we show in Fig. 9b the cumulative distribution function of daily HI over two protected national parks: Crater Lake and Acadia NPs, located over the West and Northeast regions, respectively. We also include the impact of fire pollution in this analysis and indicate the $2050 \mathrm{HI}$ target required to reach natural background conditions by 2064 as mandated by the Regional Haze Rule.

Consistent with the $\mathrm{PM}_{2.5}$ projections, we predict a significant visibility improvement in both polluted and background conditions over the continental United States. This improvement results mainly from the large reduction in anthropogenic emissions, with the strongest absolute reductions in areas with high $\mathrm{PM}_{2.5}$ and high anthropogenic aerosol precursor emissions such as the Northeast region. In this region, our results show a reduction of up to $15 \mathrm{dv}$ (deciviews) during the cleanest days and up to $10 \mathrm{dv}$ during the most polluted events in both RCP scenarios, which corresponds to an increase of more than $75 \mathrm{~km}$ in visibility range.

The improvement in $\mathrm{PM}_{2.5}$ air quality is reflected in the projected visibility over the US national parks and wilderness areas. For example, in Acadia NP, we find that both RCP scenarios predict HI level decreases of about $10 \mathrm{dv}$ during the most polluted events, leading to an improvement in visibility range of more than $70 \mathrm{~km}$. This NP is estimated to

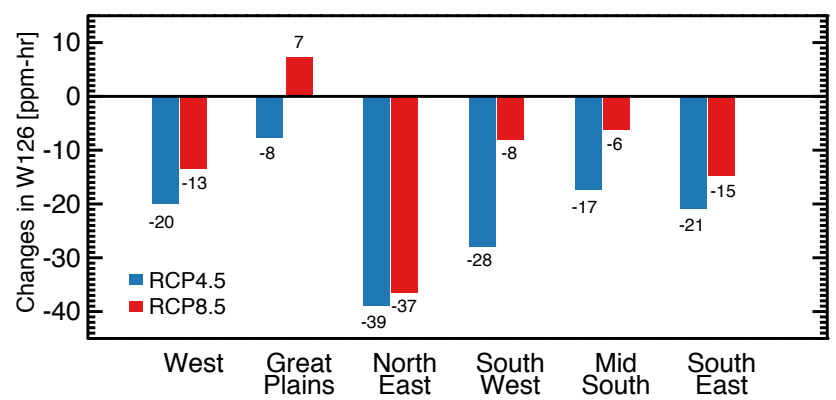

Figure 12. Simulated 2050-2000 summertime changes in $\mathrm{O}_{3} \mathrm{~W} 126$ for RCP4.5 (blue) and RCP8.5 (red) averaged over the six US climatic regions identified in Fig. 4. Numerals indicate the simulated changes in $\mathrm{O}_{3} \mathrm{~W} 126\left(\mathrm{ppmh}^{-1}\right)$.

reach the 2050 target to restore natural visibility conditions by 2064 , even during most polluted conditions. However, this is not the case for all the protected NPs and wilderness areas. Our results show that visibility in Crater Lake NP is estimated to improve by 2050 , with moderate HI decreases ( $\sim 4 \mathrm{dv}$ ) predicted by both RCP scenarios, and a general improvement of visibility range of $30-40 \mathrm{~km}$. However, HI levels are predicted to remain higher than the 2050 target. This is also the case for other important NPs located in the western US such as Yellowstone, Grand Canyon, and Mount Rainier NPs; about 40 and $74 \%$ of the total parks may not reach the 2050 target as predicted by the RCP4.5 and RCP8.5 scenarios, respectively.

Future regional visibility may also be impaired by fire pollution resulting from climate change. We find that fire pollution may maintain visibility levels at present-day conditions during the most polluted events in some NPs and wilderness areas (e.g., Crater Lake NP; Fig. 9b) or may impede the attainment of the 2050 visibility target (e.g., Yellowstone NP; not shown). Our analysis shows little or no effect of fire in visibility impairment in NPs and wilderness areas located in the Northeast and Southeast climatic regions (e.g., Acadia NP; Fig. 9b). Yue et al. (2013) estimate that future fire activity would lead to an average visibility decrease of $30 \mathrm{~km}$ in the 32 Federal Class I areas located in Rocky Mountains Forest. Our predictions for the Rocky Mountain NP show more moderate decreases in visibility (4-6 km; not shown). However, our work differs from Yue et al. (2013) in both the model resolution (200 vs. $400 \mathrm{~km}$ ) and the spatial distribution of the fire emissions.

\section{Future changes in surface $\mathrm{O}_{3}$}

In this section, we first examine future projections on daily surface MDA-8 $\mathrm{O}_{3}$ concentrations and evaluate the contributing factors to this future change. We then discuss how future changes in surface $\mathrm{O}_{3}$ may impact ecosystems. 


\subsection{Predictions of daily $\mathrm{O}_{3}$ concentrations}

Figure 10 shows the 2050-2000 changes in annual mean surface $\mathrm{O}_{3}$ concentrations predicted by the RCP4.5 and RCP8.5 scenarios in the continental United States. As in the $\mathrm{PM}_{2.5}$ analysis, we present total changes in the simulated daily MDA-8 $\mathrm{O}_{3}$ concentrations and show the individual perturbations resulting from changing climate, land use, and emissions including methane concentrations (Fig. 10a). We also highlight the regions with confidence levels higher than $95 \%$ from the Student $t$ test.

The combined effects of changing emissions, climate and land use produce a strong decrease in surface $\mathrm{O}_{3}$ across the continental US in the RCP4.5 scenario, with the strongest absolute reductions (up to $10 \mathrm{ppb}$ ) over the eastern US and California, regions with the highest $\mathrm{O}_{3}$ concentrations (Fig. 2a) and strongest anthropogenic precursors emission reductions. The average MDA- 8 over the US decreases from $52 \mathrm{ppb}$ to $47 \mathrm{ppb}$ from present to future days. However, the RCP8.5 scenario predicts important increases over the Great Plains region (about $5 \mathrm{ppb}$ ) and marginal decreases (about $2 \mathrm{ppb}$ ) over the eastern US and California. During the summertime (not shown), these changes are similar but more pronounced because $\mathrm{O}_{3}$ concentrations are the highest during this season: summertime MDA- 8 decreases from 62 to $51 \mathrm{ppb}$ in the RCP4.5 scenario and increases (about $6 \mathrm{ppb}$ ) over the Great Plains region and decreases (up to $15 \mathrm{ppb}$ ) over the eastern US and California in the RCP8.5 scenario.

The RCP4.5 and RCP8.5 scenarios project strong and similar decreases in domestic $\mathrm{O}_{3}$ precursor emissions (Table 2); however, global $\mathrm{CH}_{4}$ concentrations are $50 \%$ larger in RCP8.5 compared to RCP4.5 (2740 vs. 1838 ppb; Table 1). Rising surface $\mathrm{O}_{3}$ levels over the central US in the RCP8.5 scenario are therefore the result of elevated background $\mathrm{O}_{3}$ due to rising $\mathrm{CH}_{4}$ levels in combination with climate and land use changes. These individual effects can be clearly seen in Fig. 10b, which shows that climate and land use changes completely offset the emission reductions over the West and Midsouth regions in the RCP8.5 scenario. For example, in the West region, the RCP8.5 scenario predicts an overall increase of $3 \%$ in surface $\mathrm{O}_{3}(\sim 3 \mathrm{ppb})$, in which the contribution from emission reductions $(-2 \%)$ is counterbalanced by climate $(+3 \%)$ and land $(+2 \%)$ changes.

The impact of the rising background $\mathrm{O}_{3}$ in the RCP8.5 scenario can also be seen on the surface $\mathrm{O}_{3}$ concentrations over the ocean. Similar to previous studies (e.g., Wu et al., 2008; Fiore et al., 2012), the RCP4.5 scenario projects a decrease in $\mathrm{O}_{3}$ levels (up to $5 \mathrm{ppb}$ ) over the Pacific and Atlantic oceans in a changing climate due to the decrease of $\mathrm{O}_{3}$ lifetime associated with higher water vapor. The shorter lifetime of PAN (peroxyacetyl nitrate) in a future climate may also contribute to the decrease of $\mathrm{O}_{3}$ levels over remote areas (e.g., Wu et al., 2008; Doherty et al., 2013). By contrast, the RCP8.5 scenario projects an increase in surface $\mathrm{O}_{3}$ (up to $8 \mathrm{ppb}$ ) due to the rising background over these remote regions.
Climate and land use changes alone are also expected to significantly impact future $\mathrm{O}_{3}$ air quality. When only climate change is considered and the emissions of ozone precursors are held at present-day levels ("climate" simulation), simulated surface $\mathrm{O}_{3}$ increases by 1 and 2 ppb across the US in the RCP4.5 and RCP8.5 scenarios, respectively, with the largest absolute changes over the eastern US (up to 3 and $5 \mathrm{ppb}$, respectively). Note that this "climate penalty" does not include the effect of changing biogenic emissions, which is incorporated in the land use change simulations. However, Tai et al. (2013) show that the offsetting effects of climate and $\mathrm{CO}_{2}$ inhibition substantially reduce the role of isoprene emission changes in the climate penalty. Thus, the climate effect shown here may be a good proxy for the climate penalty and is comparable to values shown by Tai et al. (2013). In the land use change simulation, surface $\mathrm{O}_{3}$ increases by $2 \mathrm{ppb}$ in both scenarios, with the largest increases over the central US (up to 8 and $4 \mathrm{ppb}$, respectively). Increases in surface $\mathrm{O}_{3}$ result mainly from climate-driven increases in biogenic VOCs and, to a lesser extent, from a decrease in dry deposition velocity due to the shift from croplands to grasslands projected in both scenarios over this region. It is clear that our land use impacts may be slightly overestimated because we do not include the effect of $\mathrm{CO}_{2}$ inhibition in our isoprene emissions, as discussed in Sect. 2.1. However, this does not change the positive effect that changes in land use cover have on surface ozone concentrations.

Our projected change in surface $\mathrm{O}_{3}$ is more moderate than that reported in previous studies (e.g., Tagaris et al., 2007; Nolte et al., 2008; Kelly et al., 2012; Pfister et al., 2014). However, these studies do not account for changes in land cover, which our work indicates can be regionally quite substantial. Furthermore, Parrish et al. (2014) show that models (including CAM-Chem) typically underestimate the $\mathrm{O}_{3}$ response to emission changes; thus, our sensitivities likely represent a lower limit, and even larger emission-driven changes in surface $\mathrm{O}_{3}$ concentrations may be anticipated in coming decades. Finally, it is important to note that the effects of emissions, climate and land use need to be considered together when studying changes in surface $\mathrm{O}_{3}$ since these individual forcings interact in a strongly non-linear fashion. For example, surface $\mathrm{O}_{3}$ changes in the RCP8.5 scenario are $15 \%$ larger in the linear sum of the individual forcings than in the combined effects.

Figure 11 shows the impact of these changes on surface $\mathrm{O}_{3}$ over the US national parks and wilderness areas. Under RCP8.5 conditions, we find an improvement of surface $\mathrm{O}_{3}$ air quality for most polluted days (i.e., the high tail of the distribution is lower than for present-day), except in the Great Plains region, and a deterioration in the background $\mathrm{O}_{3}$ (i.e., the low tail of the distribution is higher than for present-day) all across the United States. These results are due to increases in $\mathrm{CH}_{4}$ emissions in combination with the effects of climate and land use changes as discussed above. However, under RCP4.5 conditions, there is a clear general improvement of 
surface $\mathrm{O}_{3}$ air quality across the US, with the exception of increasing background $\mathrm{O}_{3}$ in the Northeast, Southeast and Midsouth regions. Furthermore, as discussed in Pfister et al. (2014), background $\mathrm{O}_{3}$ at high elevations may be affected by long-range transport of pollution and stratospheric intrusions (e.g., Eyring et al., 2010; Lin et al., 2012). Both processes are taken into account in our simulations (but not disaggregated) and are expected to change in the future due to decreasing $\mathrm{NO}_{\mathrm{x}}$ emissions in Asia (van Vuuren et al., 2011) and the recovery of the stratosphere $\mathrm{O}_{3}$ layer (Eyring et al., 2010; Kawase et al., 2011).

In all of the US protected NPs and wilderness areas (Table 4), surface $\mathrm{O}_{3}$ levels are predicted to improve under the RCP4.5 scenario. We estimate that annual concentrations are projected to be below the current primary EPA NAAQS of $75 \mathrm{ppb}$ to protect public health, and even below a more restrictive potential future standard of $65 \mathrm{ppb}$. In contrast, under RCP8.5 conditions, numerous parks and wilderness areas are predicted to have poorer $\mathrm{O}_{3}$ air quality. For example, 34 out of the 46 protected NPs in the lower 48 states may encounter surface $\mathrm{O}_{3}$ increases with respect to presentday levels (e.g., Glacier and Yellowstone NPs), although projected concentrations are below $65 \mathrm{ppb}$. However, during the summer, when $\mathrm{O}_{3}$ concentrations are higher, 16 out of 46 NPs are predicted to have summertime surface $\mathrm{O}_{3}$ levels above 65 ppb (e.g., Rocky Mountain and Yosemite NPs; not shown).

\subsection{Effects on future ecosystem $\mathrm{O}_{3}$ damage}

To investigate the effect of projected changes in surface $\mathrm{O}_{3}$ levels in the US NPs and wilderness areas, we use the secondary metric W126 established to protect ecosystems and crops. Figure 12 presents average W126 over the US NPs and wilderness areas divided in the six climatic regions for present-day and future periods. We focus on summertime W126, as the summer season is the growing season for many ecosystems, and show the 2050-2000 difference in W126 to minimize the influence of the positive bias in the simulated W126 index, as discussed in Sect. 2.2.

Consistent with the daily $\mathrm{O}_{3}$ pattern, the RCP4.5 and RCP8.5 scenarios project a decrease in the W126 index across the continental US, with the exception of the Great Plains region by the RCP 8.5 scenario. The RCP4.5 scenario projects a general decline in W126: from strong decreases $\left(-39 \mathrm{ppm} \mathrm{h}^{-1}\right)$ in the Northeast to more moderate decreases $\left(-8 \mathrm{ppm} \mathrm{h}^{-1}\right)$ in the Great Plains. Under RCP8.5 conditions, the changes in W126 are more modest, with decreases of $-37 \mathrm{ppm} \mathrm{h}^{-1}$ in the Northeast and increases of $+7 \mathrm{ppm} \mathrm{h}^{-1}$ in the Great Plains. Despite the general decrease in daily surface $\mathrm{O}_{3}$ predicted by both scenarios from strong emission reductions, our results suggest that the decreases in the W126 index may not be sufficient to keep W126 above the suggested range for a secondary standard $\left(7-15 \mathrm{ppm} \mathrm{h}^{-1}\right)$ to protect vegetation (not shown); however, this is difficult to quantitatively assess here given the current model bias.

The simulated W126 over the US protected NPs is summarized in Table 4. Our study shows that a number of protected NPs will experience W126 levels exceeding the secondary standard to protect vegetation. The RCP8.5 scenario projects that the majority of the protected parks will have a W126 index above the recommended limits, with 34 parks above $7 \mathrm{ppm} \mathrm{h}^{-1}$ and 26 parks above $15 \mathrm{ppm} \mathrm{h}^{-1}$; projections from the RCP4.5 result in 26 and 6 parks, respectively. We note that our results indicate an upper limit on the impacts of surface $\mathrm{O}_{3}$ concentrations on vegetation given the model positive bias in the W126 index. Nonetheless, this study suggests that $\mathrm{O}_{3}$ pollution may remain a threat to ecosystems in the US NPs and wilderness areas despite the substantial general decrease in surface $\mathrm{O}_{3}$ concentrations.

\section{Conclusions}

We have quantified for the first time changes in air quality between the present and a 2050 future period associated with changes in emissions, climate, and land use change over the United States. In particular, we focus on the implications of these projections for air quality in national parks and wilderness areas.

We find that, if stringent domestic emission controls are applied in the future such as those projected by the RCP4.5 and RCP8.5 scenarios, air quality is predicted to improve significantly across the US, except for surface $\mathrm{O}_{3}$ in the central US under RCP8.5 conditions. We estimate that $\mathrm{PM}_{2.5}$ concentrations in the majority of the US NPs and wilderness areas will be substantially reduced, below the annual US EPA NAAQS of $12 \mu \mathrm{g} \mathrm{m}^{-3}$. In addition, visibility will be in general significantly improved. Over the eastern US, we estimate that most of the parks will reach the 2050 target to restore visibility to natural conditions by 2064 , whereas some parks may not reach this target during the most polluted episodes over the western US (e.g., Yellowstone and Grand Canyon NPs). This result suggests that, to obtain acceptable future visibility conditions over this region, the US National Park Service may have to develop specific air quality management plans to include further mitigation strategies beyond those projected by the RCP scenarios.

Our analysis shows that climate-driven fires may dominate summertime $\mathrm{PM}_{2.5}$ concentrations in the future over the western US, potentially offsetting the large $\mathrm{PM}_{2.5}$ reductions from anthropogenic emission controls. Future regional visibility is also estimated to be impaired by fire pollution, which may keep visibility at present-day levels during the most polluted episodes in many parks (e.g., Crater Lake NP). However, our analysis has important limitations. For example, it considers an average fire emission projection based on SRES A1B climate and applies this projection homogeneously to all the fire species on a monthly basis and with the spatial 
distribution formulated by the RCP fire emission database. More work is needed to directly couple climate-driven fire emissions, vegetation dynamics and air quality.

We find that daily surface $\mathrm{O}_{3}$ is projected to drop in all US NPs and wilderness areas in the RCP4.5 scenario, with MDA-8 levels below the primary US EPA NAAQS of $75 \mathrm{ppb}$ to protect human health and even below $65 \mathrm{ppb}$, a level considered for future regulation. In contrast, our projections with the RCP8.5 scenario indicate that numerous parks in the western and central US are predicted to have a poorer $\mathrm{O}_{3}$ air quality, with MDA-8 above $65 \mathrm{ppb}$ in some cases during the summer (e.g., Rocky Mountain and Yellowstone NPs). In this case, the rising $\mathrm{O}_{3}$ resulting from a growing $\mathrm{O}_{3}$ background associated with increases in $\mathrm{CH}_{4}$ levels $(\sim 1000 \mathrm{ppb})$ as well as climate and land use changes exceeds the important surface $\mathrm{O}_{3}$ reductions projected from anthropogenic emission controls. Furthermore, despite the substantial general decrease in surface $\mathrm{O}_{3}$, our study suggests that the secondary standard W126 may remain above the recommended limits $\left(7-15 \mathrm{ppm} \mathrm{h}^{-1}\right)$ to protect vegetation in many regions across the United States. Thus, future $\mathrm{O}_{3}$ pollution may be a threat to the US NP ecosystems. In the US, W126 levels are most sensitive to domestic anthropogenic $\mathrm{NO}_{\mathrm{x}}$ emissions (Lapina et al., 2014) and our results suggest that more restricted policies for $\mathrm{NO}_{\mathrm{x}}$ control may be needed to preserve natural ecosystems in the US NPs and wilderness areas.

Our results suggest that 2050 air quality in the US will likely be dominated by anthropogenic emission trajectories. Changes in air quality driven by climate and land use are small over the 50-year time horizon studied here and they are not always significant. However, climate alone can lead to a substantial increase in surface MDA- $8 \mathrm{O}_{3}$ by 2050 over most of the US with important implications for $\mathrm{O}_{3}$ air quality and ecosystem health degradation at the US national parks. Projected changes in temperature, cloud cover, and biogenic emissions suggest that these drivers may exacerbate future $\mathrm{O}_{3}$ pollution across the United States. Furthermore, land use change may have an important regional effect on surface $\mathrm{O}_{3}$, due to changes in biogenic emissions and dry deposition. Our study suggests that the effects of climate, vegetation, and fires are important in future air quality projections and these processes should be considered in air quality management and planning in the coming decades.

Acknowledgements. This work was supported by the US National Park Service (grant H2370 094000/J2350103006), the US National Science Foundation (AGS-1238109), and the JFSP (project ID 13-1-01-4). We thank Xu Yue (Yale University) and Jenny Hand (CIRAS-CSU) for helpful discussions and Samuel Albani (Cornell University) for the updated dust scheme. The CESM project is supported by the National Science Foundation and the Office of Science (BER) of the US Department of Energy. Computing resources were provided by the Climate Simulation Laboratory at NCAR's Computational and Information Systems Laboratory (CISL), sponsored by the National Science Foundation and other agencies. The National Center for Atmospheric Research is operated by the University Corporation for Atmospheric Research under sponsorship of the National Science Foundation. Any opinions, findings, and conclusions or recommendations expressed in this material are those of the author(s) and do not necessarily reflect the views of the National Science Foundation.

Edited by: R. Harley

\section{References}

Albani, S., Mahowald, N. M., Perry, A. T., Scanza, R. A., Zender, C. S., Heavens, N. G., Maggi, V., Kok, J. F., and OttoBliesner, B. L.: Improved dust representation in the Community Atmosphere Model, J. Adv. Model. Earth Syst., 06, 541-570, doi:10.1002/2013MS000279, 2014.

Arbaugh, M. J., Miller, P. R., Carroll, J. J., Takemoto, B., and Procter, T.: Relationships of ozone exposure to pine injury in the Sierra Nevada and San Bernardino Mountains of California, USA, Environ. Pollut., 101, 291-301, doi:10.1016/S02697491(98)00027-X, 1998.

Arneth, A., Harrison, S. P., Zaehle, S., Tsigaridis, K., Menon, S., Bartlein, P. J., Feichter, J., Korhola, A., Kulmala, M., O’Donnell, D., Schurgers, G., Sorvari, S., and Vesala, T.: Terrestrial biogeochemical feedbacks in the climate system, Nat. Geosci., 3, 525532, 2010.

Avnery, S., Mauzerall, D. L., Liu, J., and Horowitz, L. W.: Global crop yield reductions due to surface ozone exposure: 1 . Year 2000 crop production losses and economic damage, Atmos. Environ., 45, 2284-2296, 2011.

Doherty, R. M., Wild, O., Shindell, D. T., Zeng, G., MacKenzie, I. A., Collins, W. J., Fiore, A. M., Stevenson, D. S., Dentener, F. J., Schultz, M. G., Hess, P., Derwent, R. G., and Keating, T. J.: Impacts of climate change on surface ozone and intercontinental ozone pollution: A multi-model study, J. Geophys. Res. Atmos., 118, 3744-3763, doi:10.1002/jgrd.50266, 2013.

Emmons, L. K., Walters, S., Hess, P. G., Lamarque, J.-F., Pfister, G. G., Fillmore, D., Granier, C., Guenther, A., Kinnison, D., Laepple, T., Orlando, J., Tie, X., Tyndall, G., Wiedinmyer, C., Baughcum, S. L., and Kloster, S.: Description and evaluation of the Model for Ozone and Related chemical Tracers, version 4 (MOZART-4), Geosci. Model Dev., 3, 43-67, doi:10.5194/gmd3-43-2010, 2010.

Eyring, V., Cionni, I., Bodeker, G. E., Charlton-Perez, A. J., Kinnison, D. E., Scinocca, J. F., Waugh, D. W., Akiyoshi, H., Bekki, S., Chipperfield, M. P., Dameris, M., Dhomse, S., Frith, S. M., Garny, H., Gettelman, A., Kubin, A., Langematz, U., Mancini, E., Marchand, M., Nakamura, T., Oman, L. D., Pawson, S., Pitari, G., Plummer, D. A., Rozanov, E., Shepherd, T. G., Shibata, K., Tian, W., Braesicke, P., Hardiman, S. C., Lamarque, J. F., Morgenstern, O., Pyle, J. A., Smale, D., and Yamashita, Y.: Multimodel assessment of stratospheric ozone return dates and ozone recovery in CCMVal-2 models, Atmos. Chem. Phys., 10, 94519472, doi:10.5194/acp-10-9451-2010, 2010.

Fiore, A. M., Dentener, F. J., Wild, O., Cuvelier, C., Schultz, M. G., Hess, P., Textor, C., Schulz, M., Doherty, R. M., Horowitz, L. W., MacKenzie, I. A., Sanderson, M. G., Shindell, D. T., Steven- 
son, D. S., Szopa, S., Van Dingenen, R., Zeng, G., Atherton, C., Bergmann, D., Bey, I., Carmichael, G., Collins, W. J., Duncan, B. N., Faluvegi, G., Folberth, G., Gauss, M., Gong, S., Hauglustaine, D., Holloway, T., Isaksen, I. S. A., Jacob, D. J., Jonson, J. E., Kaminski, J. W., Keating, T. J., Lupu, A., Marmer, E., Montanaro, V., Park, R. J., Pitari, G., Pringle, K. J., Pyle, J. A., Schroeder, S., Vivanco, M. G., Wind, P., Wojcik, G., Wu, S., and Zuber, A.: Multimodel estimates of intercontinental sourcereceptor relationships for ozone pollution, J. Geophys. Res., 114, D04301, doi:10.1029/2008JD010816, 2009.

Fiore, A. M., Naik, V., Spracklen, D. V., Steiner, A., Unger, N., Prather, M., Bergmann, D., Cameron-Smith, P. J., Cionni, I., Collins, W. J., Dalsoren, S., Eyring, V., Folberth, G. A., Ginoux, P., Horowitz, L. W., Josse, B., Lamarque, J.-F., MacKenzie, I. A., Nagashima, T., O'Connor, F. M., Righi, M., Rumbold, S. T., Shindell, D. T., Skeie, R. B., Sudo, K., Szopa, S., Takemura, T., and Zeng, G.: Global air quality and climate, Chem. Soc. Rev., 41, 6663-6683, doi:10.1039/C2CS35095E, 2012.

Ganzeveld, L., Bouwman, L., Stehfest, E., van Vuuren, D. P., Eickhout, B., and Lelieveld, J.: Impact of future land use and land cover changes on atmospheric chemistry-climate interactions, J. Geophys. Res., 115, D23301, doi:10.1029/2010JD014041, 2010.

Ghude, S. D., Jena, C., Chate, D. M., Beig, G., Pfister, G. G., Kumar, R., and Ramanathan, V.: Reductions in India's crop yield due to ozone, Geophys. Res. Lett., 41, 5685-5691, doi:10.1002/2014GL060930, 2014.

Guenther, A. B., Jiang, X., Heald, C. L., Sakulyanontvittaya, T., Duhl, T., Emmons, L. K., and Wang, X.: The Model of Emissions of Gases and Aerosols from Nature version 2.1 (MEGAN2.1): an extended and updated framework for modeling biogenic emissions, Geosci. Model Dev., 5, 1471-1492, doi:10.5194/gmd-51471-2012, 2012.

Hand, J. L., Schichtel, B. A., Malm, W. C., and Pitchford, M. L.: Particulate sulfate ion concentration and $\mathrm{SO}_{2}$ emission trends in the United States from the early 1990s through 2010, Atmos. Chem. Phys., 12, 10353-10365, doi:10.5194/acp-1210353-2012, 2012.

Heald, C. L., Henze, D. K., Horowitz, L. W., Feddema, J., Lamarque, J.-F., Guenther, A., Hess, P. G., Vitt, F., Seinfeld, J. H., Goldstein, A. H., and Fung, I.: Predicted change in global secondary organic aerosol concentrations in response to future climate, emissions, and land use change, J. Geophys. Res. Atmos., 113, D05211, doi:10.1029/2007JD009092, 2008.

Hollaway, M. J., Arnold, S. R., Challinor, A. J., and Emberson, L. D.: Intercontinental trans-boundary contributions to ozoneinduced crop yield losses in the Northern Hemisphere, Biogeosciences, 9, 271-292, doi:10.5194/bg-9-271-2012, 2012.

Horowitz, L. W., Fiore, A. M., Milly, G. P., Cohen, R. C., Perring, A., Wooldridge, P. J., Hess, P. G., Emmons, L. K., and Lamarque, J.-F.: Observational constraints on the chemistry of isoprene nitrates over the eastern United States, J. Geophys. Res. Atmos., 112, D12S08, doi:10.1029/2006JD007747, 2007.

Hurtt, G., Chini, L., Frolking, S., Betts, R., Feddema, J., Fischer, G., Fisk, J., Hibbard, K., Houghton, R., Janetos, A., Jones, C., Kindermann, G., Kinoshita, T., Klein Goldewijk, K., Riahi, K., Shevliakova, E., Smith, S., Stehfest, E., Thomson, A., Thornton, P., Vuuren, D., and Wang, Y.: Harmonization of land-use scenarios for the period 1500-2100: 600 years of global gridded annual land-use transitions, wood harvest, and resulting sec- ondary lands, Clim. Change, 109, 117-161, doi:10.1007/s10584011-0153-2, 2011.

IPCC: in: Climate Change 2013: The Physical Science Basis, edited by Stocker, T., Qin, D., Plattner, G.-K., Tignor, M., Allen, S., Boschung, J., Nauels, A., Y. Xia, V. B., and Midgley, P., Cambridge University Press, Cambridge, United Kingdom and New York, NY, USA, 1535 pp, 2013.

Jacob, D. J. and Winner, D. A.: Effect of climate change on air quality, Atmos. Environ., 43, 51-63, doi:10.1016/j.atmosenv.2008.09.051, Fifty Years of Endeavour, Atmos. Environ., 2009.

Kawase, H., Nagashima, T., Sudo, K., and Nozawa, T.: Future changes in tropospheric ozone under Representative Concentration Pathways (RCPs), Geophys. Res. Lett., 38, L05801, doi:10.1029/2010GL046402, 2011.

Kaynak, B., Hu, Y., Martin, R. V., Russell, A. G., Choi, Y., and Wang, Y.: The effect of lightning $\mathrm{NO}_{\mathrm{x}}$ production on surface ozone in the continental United States, Atmos. Chem. Phys., 8, 5151-5159, doi:10.5194/acp-8-5151-2008, 2008.

Kelly, J., Makar, P. A., and Plummer, D. A.: Projections of mid-century summer air-quality for North America: effects of changes in climate and precursor emissions, Atmos. Chem. Phys., 12, 5367-5390, doi:10.5194/acp-12-5367-2012, 2012.

Lack, D. A., Tie, X. X., Bofinger, N. D., Wiegand, A. N., and Madronich, S.: Seasonal variability of secondary organic aerosol: A global modeling study, J. Geophys. Res. Atmos., 109, D03203, doi:10.1029/2003JD003418, 2004.

Lam, Y. F., Fu, J. S., Wu, S., and Mickley, L. J.: Impacts of future climate change and effects of biogenic emissions on surface ozone and particulate matter concentrations in the United States, Atmos. Chem. Phys., 11, 4789-4806, doi:10.5194/acp-11-47892011, 2011.

Lamarque, J.-F., Bond, T. C., Eyring, V., Granier, C., Heil, A., Klimont, Z., Lee, D., Liousse, C., Mieville, A., Owen, B., Schultz, M. G., Shindell, D., Smith, S. J., Stehfest, E., Van Aardenne, J., Cooper, O. R., Kainuma, M., Mahowald, N., McConnell, J. R., Naik, V., Riahi, K., and van Vuuren, D. P.: Historical (1850-2000) gridded anthropogenic and biomass burning emissions of reactive gases and aerosols: methodology and application, Atmos. Chem. Phys., 10, 7017-7039, doi:10.5194/acp10-7017-2010, 2010.

Lamarque, J.-F., Emmons, L. K., Hess, P. G., Kinnison, D. E., Tilmes, S., Vitt, F., Heald, C. L., Holland, E. A., Lauritzen, P. H., Neu, J., Orlando, J. J., Rasch, P. J., and Tyndall, G. K.: CAMChem: description and evaluation of interactive atmospheric chemistry in the Community Earth System Model, Geosci. Model Dev., 5, 369-411, doi:10.5194/gmd-5-369-2012, 2012.

Lapina, K., Henze, D. K., Milford, J. B., Huang, M., Lin, M., Fiore, A. M., Carmichael, G., Pfister, G. G., and Bowman, K.: Assessment of source contributions to seasonal vegetative exposure to ozone in the US, J. Geophys. Res. Atmos., 119, 324-340, doi:10.1002/2013JD020905, 2014.

Lefohn, A. S., Laurence, J. A., and Kohut, R. J.: A comparison of indices that describe the relationship between exposure to ozone and reduction in the yield of agricultural crops, Atmos. Environ., 22, 1229-1240, doi:10.1016/0004-6981(88)90353-8, 1988.

Leibensperger, E. M., Mickley, L. J., Jacob, D. J., Chen, W.-T., Seinfeld, J. H., Nenes, A., Adams, P. J., Streets, D. G., Kumar, N., and Rind, D.: Climatic effects of 1950-2050 changes in US anthro- 
pogenic aerosols, Part 1: Aerosol trends and radiative forcing, Atmos. Chem. Phys., 12, 3333-3348, doi:10.5194/acp-12-33332012, 2012.

Leung, L. R. and Gustafson, W. I.: Potential regional climate change and implications to US air quality, Geophys. Res. Lett., 32, L16711, doi:10.1029/2005GL022911, 2005.

Lin, M., Fiore, A. M., Horowitz, L. W., Cooper, O. R., Naik, V., Holloway, J., Johnson, B. J., Middlebrook, A. M., Oltmans, S. J., Pollack, I. B., Ryerson, T. B., Warner, J. X., Wiedinmyer, C., Wilson, J., and Wyman, B.: Transport of Asian ozone pollution into surface air over the western United States in spring, J. Geophys. Res. Atmos., 117, D00V07, doi:10.1029/2011JD016961, 2012.

Mahowald, N. M., Lamarque, J.-F., Tie, X. X., and Wolff, E.: Seasalt aerosol response to climate change: Last Glacial Maximum, preindustrial, and doubled carbon dioxide climates, J. Geophys. Res. Atmos., 111, D05303, doi:10.1029/2005JD006459, 2006 a.

Mahowald, N. M., Muhs, D. R., Levis, S., Rasch, P. J., Yoshioka, M., Zender, C. S., and Luo, C.: Change in atmospheric mineral aerosols in response to climate: Last glacial period, preindustrial, modern, and doubled carbon dioxide climates, J. Geophys. Res. Atmos., 111, D10202, doi:10.1029/2005JD006653, 2006b.

Malm, W. C. and Hand, J. L.: An examination of the physical and optical properties of aerosols collected in the IMPROVE program, Atmos. Environ., 41, 3407-3427, doi:10.1016/j.atmosenv.2006.12.012, 2007.

Mao, J., Paulot, F., Jacob, D. J., Cohen, R. C., Crounse, J. D., Wennberg, P. O., Keller, C. A., Hudman, R. C., Barkley, M. P., and Horowitz, L. W.: Ozone and organic nitrates over the eastern United States: Sensitivity to isoprene chemistry, J. Geophys. Res. Atmos., 118, 11256-11268, doi:10.1002/jgrd.50817, 2013.

Meehl, G. A., Hu, A., Tebaldi, C., Arblaster, J. M., Washington, Warren M.and Teng, H., Sanderson, B. M., Ault, T., Strand, W. G., and White, J. B.: Relative outcomes of climate change mitigation related to temperature versus sea level and sea level rise, Nat. Clim. Change, 2, 576-580, doi:10.1038/nclimate1529, 2012.

Metzger, S., Dentener, F., Pandis, S., and Lelieveld, J.: Gas/aerosol partitioning: 1. A computationally efficient model, J. Geophys. Res. Atmos., 107, ACH 16-1-ACH 16-24, doi:10.1029/2001JD001102, 2002.

Moritz, M. A., Parisien, M.-A., Batllori, E., Krawchuk, M. A., Van Dorn, J., Ganz, D. J., and Hayhoe, K.: Climate change and disruptions to global fire activity, Ecosphere, 3, 49, doi:10.1890/ES11-00345.1, 2012.

Moss, R. H., Edmonds, J. A., Hibbard, K. A., Manning, M. R., Rose, S. K., van Vuuren, D. P., Carter, T. R., Emori, S., Kainuma, M., Kram, T., Meehl, G. A., Mitchell, J. F. B., Nakicenovic, N., Riahi, K., Smith, S. J., Stouffer, R. J., Thomson, A. M., Weyant, J. P., and Wilbanks, T. J.: The next generation of scenarios for climate change and assessment, Nature, 463, 747-756, doi:10.1038/nature08823, 2011.

Murazaki, K. and Hess, P.: How does climate change contribute to surface ozone change over the United States?, J. Geophys. Res., 111, D05301, doi:10.1029/2005JD005873, 2006.

Neale, R. B., Richter, J., Park, S., Lauritzen, P. H., Vavrus, S. J., Rasch, P. J., and Zhang, M.: The mean climate of the community atmosphere model (CAM4) in forced SST and fully coupled experiments, J. Climate, 26, 5150-5168, doi:10.1175/JCLI-D-1200236, 2013.
Nolte, C. G., Gilliland, A. B., Hogrefe, C., and Mickley, L. J.: Linking global to regional models to assess future climate impacts on surface ozone levels in the United States, J. Geophys. Res. Atmos., 113, D14307, doi:10.1029/2007JD008497, 2008.

Oleson, K. W., Lawrence, D. M., Bonan, G. B., Flanner, M. G., Kluzek, E., Lawrence, P. J., Levis, S., Swenson, S. C., Thornton, P. E., Dai, A., M., D., Dickinson, R., Feddema, J., Heald, C. L., Hoffman, F., Lamarque, J.-F., Mahowald, N., Niu, G.-Y., Qian, T., Randerson, J., Running, S., Sakaguchi, K., Slater, A., Stockli, R., Wang, A., Yang, Z.-L., and Zeng, X.: Technical description of version 4.0 of the Community Land Model (CLM), Tech. Rep. Technical Note NCAR/TN-478+STR, 257 pp., NCAR, 2010.

Parrish, D. D., Lamarque, J.-F., Naik, V., Horowitz, L., Shindell, D. T., Staehelin, J., Derwent, R., Cooper, O. R., Tanimoto, H., Volz-Thomas, A., Gilge, S., Scheel, H.-E., Steinbacher, M., and Fröhlich, M.: Long-term changes in lower tropospheric baseline ozone concentrations: Comparing chemistry-climate models and observations at northern midlatitudes, J. Geophys. Res. Atmos., 119, 5719-5736, doi:10.1002/2013JD021435, 2014.

Pfister, G. G., Walters, S., Lamarque, J.-F., Fast, J., Barth, M. C., Wong, J., Done, J., Holland, G., and Brussere, C. L.: Projections of future summertime ozone over the US, J. Geophys. Res. Atmos., 119, 5559-5582, doi:10.1002/2013JD020932, 2014.

Pitchford, M. L. and Malm, W. C.: Development and applications of a standard visual index, Atmos. Environ., 28, 1049-1054, doi:10.1016/1352-2310(94)90264-X, 1994.

Pope, C. A. and Dockery, D. W.: Health Effects of Fine Particulate Air Pollution: Lines that Connect, J. Air Waste Manage. Asso., 56, 709-742, doi:10.1080/10473289.2006.10464485, 2006.

Pye, H. O. T., Liao, H., Wu, S., Mickley, L. J., Jacob, D. J., Henze, D. K., and Seinfeld, J. H.: Effect of changes in climate and emissions on future sulfate-nitrate-ammonium aerosol levels in the United States, J. Geophys. Res.-Atmos., 114, D01205, doi:10.1029/2008JD010701, 2009.

Racherla, P. N. and Adams, P. J.: The response of surface ozone to climate change over the Eastern United States, Atmos. Chem. Phys., 8, 871-885, doi:10.5194/acp-8-871-2008, 2008.

Reich, P. B. and Amundson, R. G.: Ambient levels of ozone reduce net photosynthesis in tree and crop species, Science, 230, 566570, doi:10.1126/science.230.4725.566, 1985.

Schaub, M., J., Skelly, J., Zhang, J., Ferdinand, J., Savage, J., Stevenson, R., Davis, D., and Steiner, K.: Physiological and foliar symptom response in the crowns of Prunus serotina, Fraxinus americana and Acer rubrum canopy trees to ambient ozone under forest conditions, Science, 133, 553-567, doi:10.1016/j.envpol.2004.06.012, 2005.

Scholze, M., Knorr, W., Arnell, N. W., and Prentice, I. C.: A climate-change risk analysis for world ecosystems, P. Natl. Acad. Sci. USA, 103, 13116-13120, doi:10.1073/pnas.0601816103, 2006.

Sitch, S., Cox, P. M., Collins, W. J., and Huntingford, C.: Indirect radiative forcing of climate change through ozone effects on the land-carbon sink, Nature, 448, 791-794, doi:10.1038/nature06059, 2007.

Spracklen, D. V., Mickley, L. J., Logan., J. A., Hudman, R. C., Yevich, R., Flannigan, M. D., and Westerling, A. L.: Impacts of climate change from 2000 to 2050 on wildfire activity and carbonaceous aerosol concentrations in the western United States, J Geophys. Res., 114, D2030, doi:10.1029/2008JD010966, 2009. 
Tagaris, E., Manomaiphiboon, K., Liao, K.-J., Leung, L. R., Woo, J.-H., He, S., Amar, P., and Russell, A. G.: Impacts of global climate change and emissions on regional ozone and fine particulate matter concentrations over the United States, J. Geophys. Res.-Atmos., 112, D14312, doi:10.1029/2006JD008262, 2007.

Tai, A. P. K., Mickley, L. J., and Jacob, D. J.: Impact of 2000-2050 climate change on fine particulate matter $\left(\mathrm{PM}_{2.5}\right)$ air quality inferred from a multi-model analysis of meteorological modes, Atmos. Chem. Phys., 12, 11329-11337, doi:10.5194/acp-1211329-2012, 2012.

Tai, A. P. K., Mickley, L. J., Heald, C. L., and Wu, S.: Effect of $\mathrm{CO}_{2}$ inhibition on biogenic isoprene emission: implications for air quality under 2000 to 2050 changes in climate, vegetation, and land use, Geophys. Res. Lett., 40, 3479-3483, doi:10.1002/grl.50650, 2013.

Tai, A. P. K., Val Martin, M., and Heald, C. L.: Threat to future global food security from climate change and ozone air pollution, Nature Climate Change, 4, 817-821, doi:10.1038/nclimate2317, 2014.

Tie, X., Madronich, S., Walters, S., Edwards, D. P., Ginoux, P., Mahowald, N., Zhang, R., Lou, C., and Brasseur, G.: Assessment of the global impact of aerosols on tropospheric oxidants, J. Geophys. Res.-Atmos., 110, D03204, doi:10.1029/2004JD005359, 2005.

Tilmes, S., Lamarque, J.-F., Emmons, L. K., Kinnison, D. E., Ma, P.-L., Liu, X., Ghan, S., Bardeen, C., Arnold, S., Deeter, M., Vitt, F., Ryerson, T., Elkins, J. W., Moore, F., and Spackman, R.: Description and evaluation of tropospheric chemistry and aerosols in the Community Earth System Model (CESM1.2), Geosci. Model Dev. Discuss., 7, 8875-8940, doi:10.5194/gmdd7-8875-2014, 2014.

Tong, D. Q., Mathur, R., Kang, D., Yu, S., Schere, K. L., and Pouliot, G.: Vegetation exposure to ozone over the continental United States: Assessment of exposure indices by the EtaCMAQ air quality forecast model, Atmos. Environ., 43, 724733, doi:10.1016/j.atmosenv.2008.09.084, 2009.
US EPA: Guidance for Estimating Natural Visibility Conditions Under the Regional Haze Rule, Tech. Rep. EPA 454/B-03-005, US Environmental Protection Agency Office of Air Quality Planning and Standards Emissions, Monitoring and Analysis Division Air Quality Trends Analysis Group, Research Triangle Park, NC, 2003.

Val Martin, M., Heald, C. L., Ford, B., Prenni, A. J., and Wiedinmyer, C.: A decadal satellite a nalysis of the origins and impacts of smoke in Colorado, Atmos. Chem. Phys., 13, 74297439, doi:10.5194/acp-13-7429-2013, 2013.

Val Martin, M., Heald, C. L., and Arnold, S. R.: Coupling dry deposition to vegetation phenology in the Community Earth System Model: implications for the simulation of surface $\mathrm{O}_{3}$, Geophys. Res. Lett., 41, 2988-2996, doi:10.1002/2014GL059651, 2014.

van Vuuren, D., Edmonds, J., Kainuma, M., Riahi, K., Thomson, A., Hibbard, K., Hurtt, G., Kram, T., Krey, V., Lamarque, J.F., Masui, T., Meinshausen, M., Nakicenovic, N., Smith, S., and Rose, S.: The representative concentration pathways: an overview, Climatic Change, 109, 5-31, doi:10.1007/s10584-0110148-z, 2011.

Wesely, M.: Parameterization of surface resistances to gaseous dry deposition in regional-scale numerical models, Atmos. Environ., 23, 1293-1304, doi:10.1016/0004-6981(89)90153-4, 1989.

Wu, S., Mickley, L. J., Jacob, D. J., Rind, D., and Streets, D. G.: Effects of 2000-2050 changes in climate and emissions on global tropospheric ozone and the policy-relevant background surface ozone in the United States, J. Geophys. Res.-Atmos., 113, D18312, doi:10.1029/2007JD009639, 2008.

Wu, S., Mickley, L. J., Kaplan, J. O., and Jacob, D. J.: Impacts of changes in land use and land cover on atmospheric chemistry and air quality over the 21 st century, Atmos. Chem. Phys., 12, 15971609, doi:10.5194/acp-12-1597-2012, 2012.

Yue, X., Mickley, L. J., Logan, J. A., and Kaplan, J. O.: Ensemble projections of wildfire activity and carbonaceous aerosol concentrations over the western United States in the mid-21st century, Atmos. Environ., 77, 767-780, doi:10.1016/j.atmosenv.2013.06.003, 2013. 